University of Louisville

ThinkIR: The University of Louisville's Institutional Repository

Electronic Theses and Dissertations

1942

\title{
A study of the origin and development of the Theodore Ahrens Trade School of Kentucky.
}

Norma Eugene Theisen

University of Louisville

Follow this and additional works at: https://ir.library.louisville.edu/etd

Part of the Education Commons

\section{Recommended Citation}

Theisen, Norma Eugene, "A study of the origin and development of the Theodore Ahrens Trade School of Kentucky." (1942). Electronic Theses and Dissertations. Paper 1946.

https://doi.org/10.18297/etd/1946

This Master's Thesis is brought to you for free and open access by ThinkIR: The University of Louisville's Institutional Repository. It has been accepted for inclusion in Electronic Theses and Dissertations by an authorized administrator of ThinkIR: The University of Louisville's Institutional Repository. This title appears here courtesy of the author, who has retained all other copyrights. For more information, please contact thinkir@louisville.edu. 


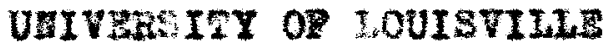

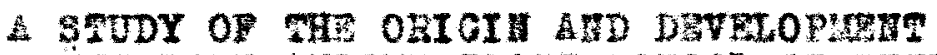

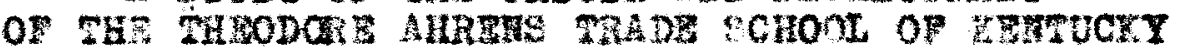

L Diasertetion

Subritted to the Fondty

Of the Greduate sohool of the Univereity of Louievilie

In portiri sulfiliment of the

hequiremente for the Degreo

of inetor of Arte

Depnrtment of enducition

by

Horta Engene Thelsen

Year

1942 
NAUE OF S TUDERT:
TITLE OF THESIS: A STUDY OF THE ORIGIN AED DEVBLOPAENT OF THR THSODOHE AHRRHS MRADE SCHOOL OF KBUTUCKY

APPEOVRD BY A RRADIHG COUAITHEF CORPOSED OF THE POLLOTIMG UMARER:
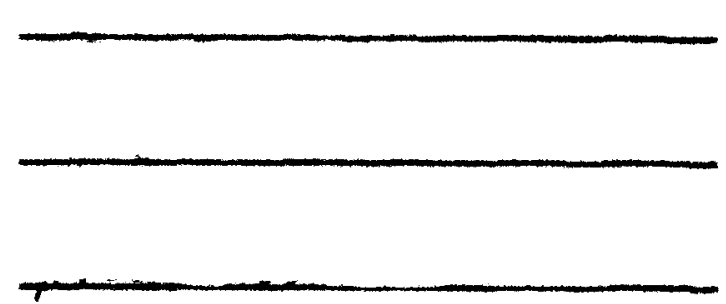

MAME OF DIRECTOR:

DATE: 


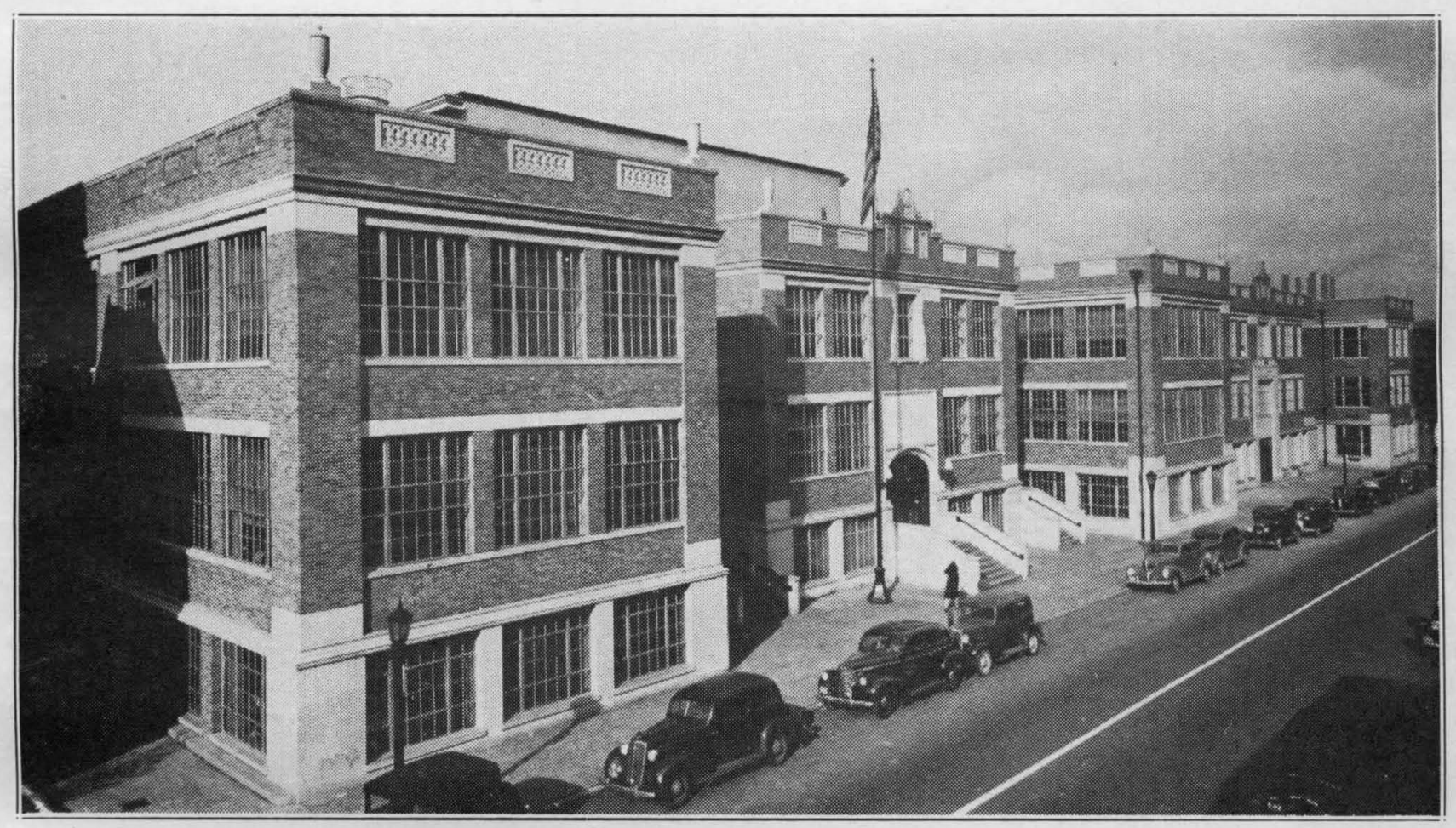




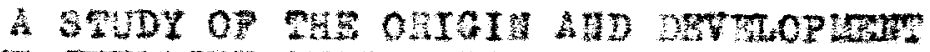

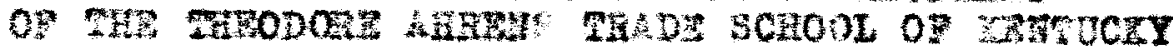




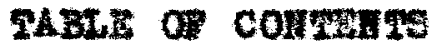

BAOB

PREYACB ....................... 1

Furposes of the etray .......... 1

14. Thoodo re khrene ana use sthel

Lovell ..................111

CHAFTs

I. IHWRODUCTIOH - VOCATIORAL BUUCATIOT

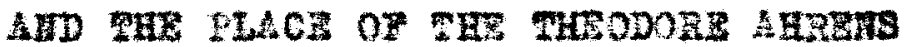

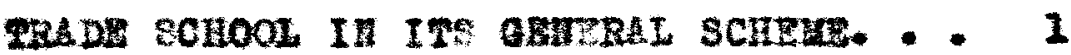

Ahrene Trade Sohool as an 112ustration

of the alm of rocetional ednoation

in Eentuokg ............ 2

the progrees of vocetional education

In Sentualy ............ 7

vocktlonal edneation a national

motement ............. 13

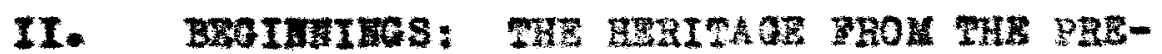

vocamional AHD vOCATIOAAL schoote . . 21

The estabilehent of the prevocetional

gchool .............. 22

The oopperation of the Consumers'

Lengue in eatsbilehing the Erevoce-

tlonal gahool ........... 24 
The problen of the prevoedtonal

Sebool ................. 32

Whe Voetional Sehool .......... 50

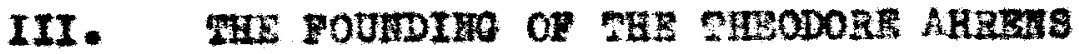

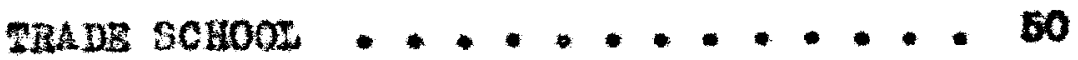

The fit zor a nov trade sohool .... 60

Preparatlone for expanaton . . . . 55

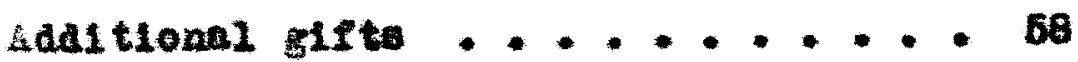

Conetruetion of the now plant . . . . 63

Dodtection of the trate gohool ....68

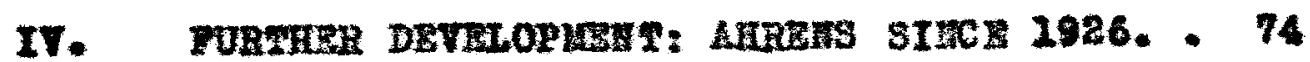

Prowth and organisation ........ 74

Later phyeloal expanalon . . . . . 87

Amene and national atonse . . . . 91

Conclaston *................ 100

BIBLIODRAgr ........................ 105 
PRAPCE 


\section{PRTPACE}

\section{WURPOS OF THE STVDT}

The in body of this the is in an seoount of the Theodore ishrens prade school of Jonleville, Kentuoky. Irom ite beginning to tho present time Chaptere II. III, and IV are ontirely devoted to the origins, Growth, and developent of thio institution. The inveatigetion covere the period of jeare trom 1913 to 1241.

In waking the otudy it has been attompted to point out the two-fold fanotion ar the ihrens zrede Sehool in conneotion with the comanity of Ionlsville: firet, in the case of the Individual atudent who sooks opeolelized treining for the onring of a livelihood: and second. In the cege of the efty'o bealnese and trade organization which is benefited by an adequnte souroe of woll-equipped workers. The fact that this value is rooognized by the comanity is cemonetrated by attention to the casidance and cooperation of verlons elty organizations in intalning and inproving the ochool.

chapter I has been used to introduce the socount by relating the Theodore Ahrons Frade school to the trend of the roostiona ancetion wovement in the ats te of Latuoky and in the nation ss whole. The developaent of thet moverant hae been indlosted in order to show how 


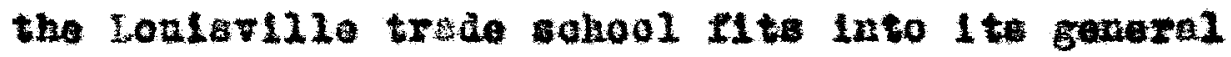
sehome. Io atteret has beon wate, howerer, to do wore then provide the bexground agalnet which the $200 a 1$ Inotitution aight bo viowad in aloarer Iight. In dolng ao, of course, bang letalle have been olininated Thich wonld have bean necesecry it fuller acoont of netiond tooktonel adnotion had bean ollod for. Sow contuaion bay be cansed by the Ireqnent nention of the revocetional and Vocetionel behoole anlose thair place in this disasion is pointed ont at the beginuing. the provoestional school wse the Iirat attengt to provide vocutionel and trade ednotion for Lonisville papils. Eotabliehed in 1913. It was ca2led by this nawe until 1918 when 14 becam known eo

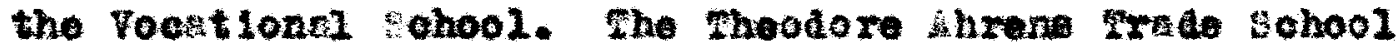
18 the ontgrowth of the es lastitutions, recolving ite

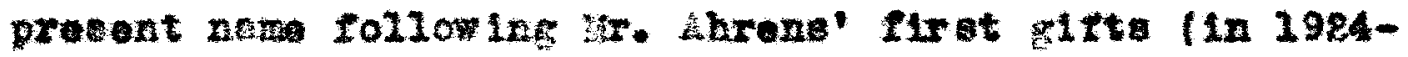
25) to expand the Yoostlound sohool.

the rhoodere Ahrent rrade Sohool is an integral

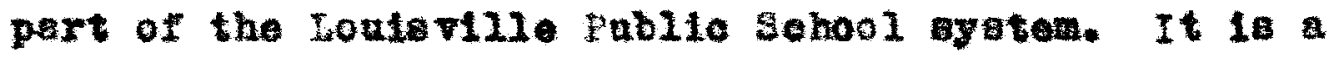
three year santor hlgh sohool, onrolling over one thousta otudente in it reguler cal releted courees. teny raeter snd persons have oontributed to ite present

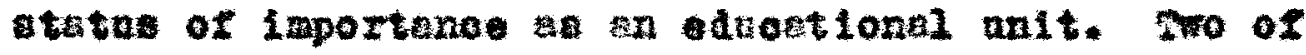
these persone hove had akoh anique plece in 1 to hlatory 


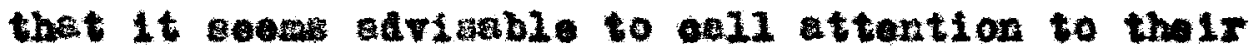
special contritutions in the part of this profsee wioh tollowe.

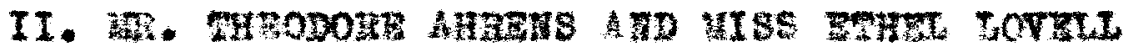

In the story of the thoodore threns Frade Bchool,

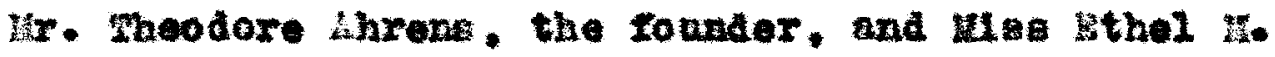
10ve21. the adminietrator, stsid in the forofront of those contributing to the influence of that inetitation. sbout fleten years go itr. Ahrone sala to the lonleville Bosra of Bduotion: "I on intereeted in bettering the condition of the youth of Louleville. I want to do eothething for the boye and girle, who, upon leaving vobool, mat ongage lanediately in the trak of - Erning a 217elihood." fhoce worde were followed by prowpt and effoctive cotlon. The reant was the foundIng of the Froodore Ameng Frode behool, Involving the oventad gift of over a hit ballion dollars. The

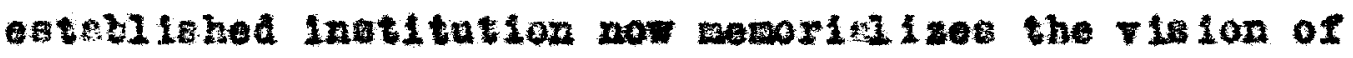
a wan whose cocomplishmote provido sa exomplo of real altisenahsp.

Born in Saltimore on teptember 21, 1869, the

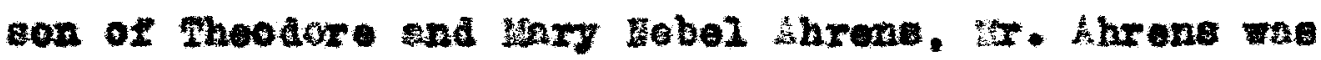
ednceted in the pabilo gehoole of Loulevilie. At the age of thirteen he ras given hil Ifre employment in hie 


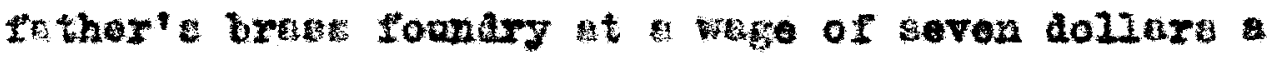

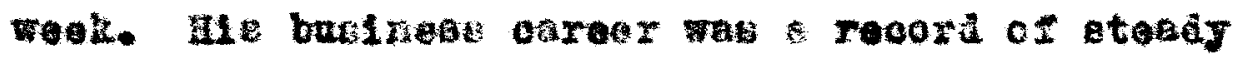
trancotent and inerobulng responsibllity. At the age

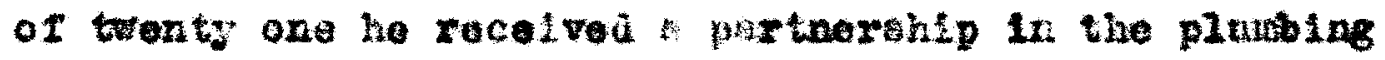

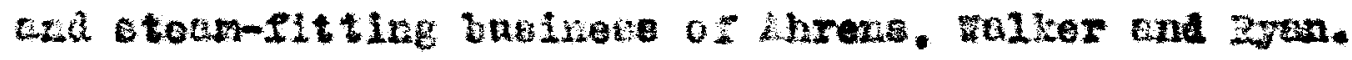
In 1305 be jolmo hio tather and renry oft is conancting the brese vort foundry. In 1894 the Ahrone and

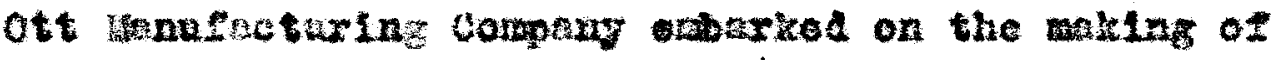
ontmoled ware and coon wse arong the ieadere in tho 1102d. In 1900 the buelnets tre ouneolldatod fith the

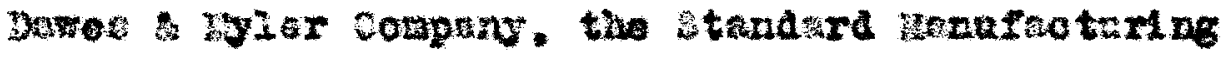

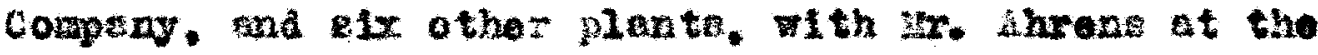
hond of the new orgenlsation.

ib. Ahrons was colf-mode wan, with very extensire education in the conditions and afratre of wen. In the gront cehool of experionce. Ho wat a tirelese worker ith nang and varlod interete ocopylng bie ettention. under his gnidance the tandera santary Hanafncturing Complay beane a groxt organization. Hevortholase, he ane interested continuonely in publlo weltere. both eductional and recrentlonal.

the Houlaville trede achool which beare tr. Shrens" nade la not the ouly oviance of his intereat in vecattonel training* In 1925 ho told his aseoctetes that he proposed to eatabush and ondow a protestonal 
chsir in plubing. Heating and Ventilating at the carnegle Institute of Teahnology et itteburgh. penniglvanin. The anownoent was epoohal for the industry and wa colulad in trade journale and newepsipers throughout the country.

The resson whl oh prompted his ank ing posalble a trode chool for the city of 5001 Eville vere mate

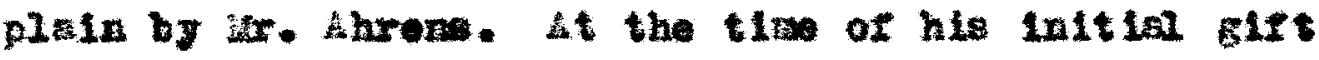
for 1 ts eatoblishment, he bald that daring the holfcenturg he had been in buelnese he had becowe arare of the noed of stendaralzed courses for boys and firlo planalng to onter trades. To expresaed the opinion that apprenticeah pe were haphazard In their training and wsiteful of tiwe snd energy on the part of employos. and he pointed to the need of trained reoruite in mochenios, expontry, pluwing. electrio installation. printing. wanonry, and awong women for dreabmare. niliners, a ther occupatione.

3r. Ahrene' Intereat in athlotion was reaponolble Lor 5 peolal contribution to anke posolblo a gransium tor the Thoodore throse prode sohool. An excellent Gyoust in his youth, he rotained hio sulration for

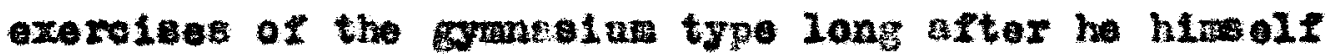
had siven them ap. Then the plone tor the school had beon ararted, they were subal tod to : An. Ahrone. "Ehere's 
the Ermasinu?" he wanted to know. Upon belng told thet the rande he be provided were ouftielett for the

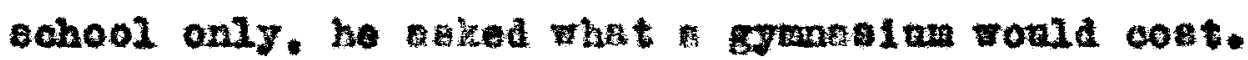
when $50,000.00$ wat engested, he greed to give the adaltionel mont.

on June 12, 1938. Wr. Ahrene died nt the sge of cerenty olght, a wan warized by his bueldose genins, his wide travel, and his great philanthropy. He left in Joulsville two monasente to hil chievement--the stendard

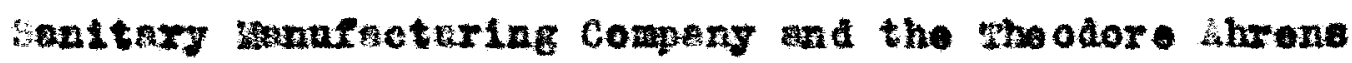
sxade soheol. It is in his relation to the lattor institution that he become laportent in the pagea of this story.

I rectore in the developrant of the shrens prade school. 1. otill the hesd of thet Institution, as whe boen

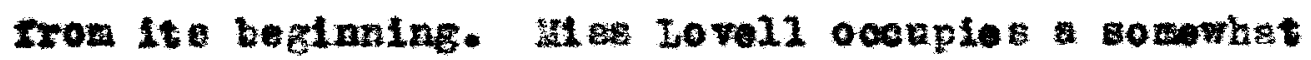
anlge and highy honor able postion in the eduationel development of Looleville. Al though a woman, ohe was

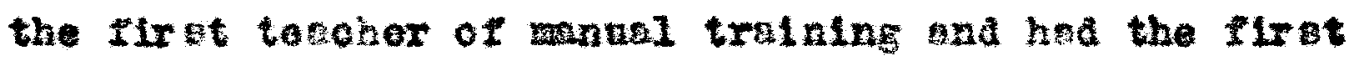
mood workshop in the publio schools of tbls afty. tat Lovell have ver been an Intense atrdent or the rootiongl in oducation. Fille ongored in her

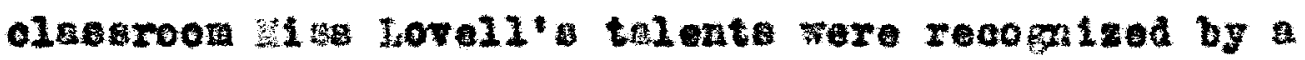
gronp of $100 \mathrm{l}$ at ab won, promotere of adranoed 
edncetion, tho sad hex to chlesgo for perlod of stady. Dpon her retturn the was ade princl pel wa Inatructor of the grevocetional sohool. Ifrat eatabI1Bhad hore in 1923-1924. IIEe Lovell wos the lotalng opirit in devialng the plen apon thich this school wes operated.

A fer yerrs later thia sobool bectue the Loulbrille Voottlonal sehool, whioh nesse we held vatil the theodore whrons Irede soheol beoans ite ancessaor in 1926.

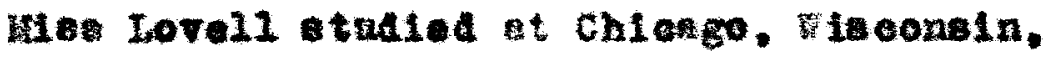

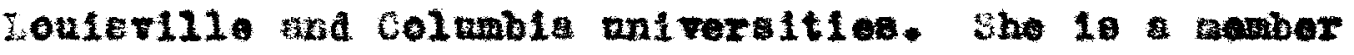
of the nstional, atate. end Ionlaville ednotional

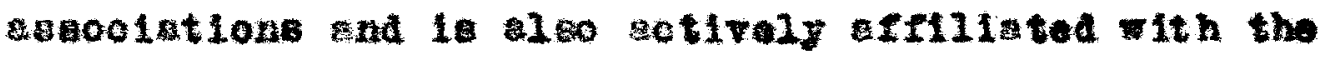

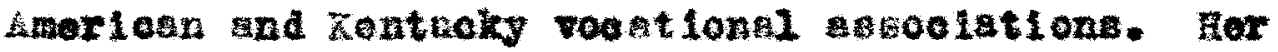
-iv10 Interet he been Hanifoeted by her connection

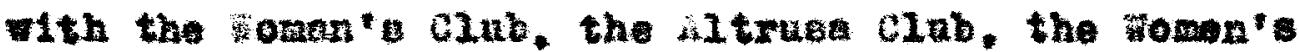
City CIab, and the Bathese and protedelonel romen's clab.

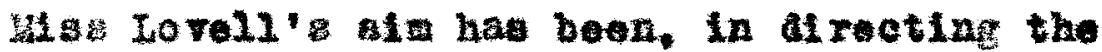

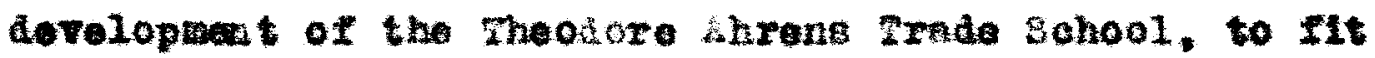
the sohool to weet the neede of the comsunity ce moll ac of the Individual atadents. Fo this ond the hou not enphes otimiate inoreanes in tho gine of its enrolimant. 
Thee have come, but they have been regulated bo as to wet the damende of mployere for workere where they have beon needed. hny other oourse, aocording to her phllotophy. vonld have weent an overapply of mortare in certajn ocouphtione and consequent, avolaable. 1 dlenes of tralned aplozees. po prevent this,

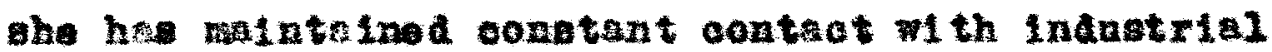
and bnolnoes alrectors sad her school hse acoospliahed

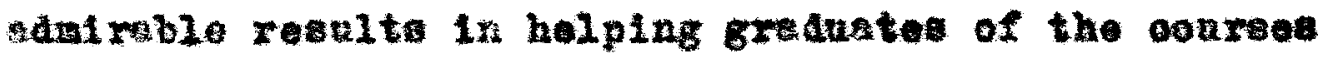
at Ahrous in obtelning and rataining employant. uteving had so large a share in the derelopment of the prosent systen of roeational eduastion hore.

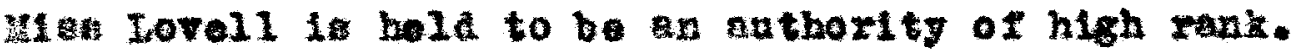
It If not to be donbted thet ander her asroction the Ahreno Frado sohool hed resched an adveneod otage of c1v10 paetulnesa.

Pron the frote whloh he been presented it lo elear that the eduotionn lnatitution dealt with in the following page owe wah to the rarlone arvices of both ar. Ahrene and Hise Lovell. It is not intonded. however. that these recte ahould obsoure the bang and raluable contributione whioh others here ade to the Theodore Ahrens prade school. Some of thete w111 presently spoen in their conneotion with the origin and devalopisent of the sohool as etualed in the chapters whioh now aveced this protroe. 


\section{C1:}

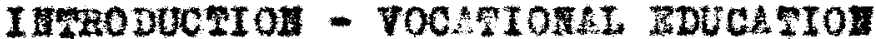

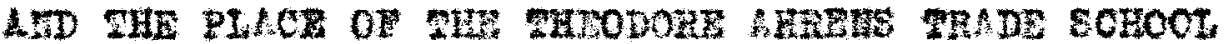

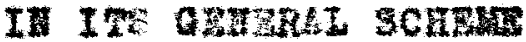

Ahren Frrde school is on of the hundrede of trode achools which hove bpune ap all over trorica durlas the pent guarter of century. It 18 an oxprestion of \& movoment which hes extered into national edtertion inoe 1900. She laportance of the school w11I be better underotood if it 1 conal cered in 1 ts rolation to state cad netional gromth of rocutional.

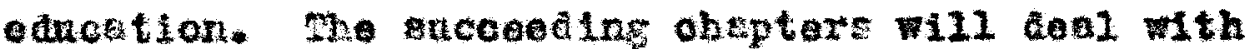
Ahreno particuler ingtitution. Here, bovover, It seowe whe to polnt ont brieny it b bokgrownd and the

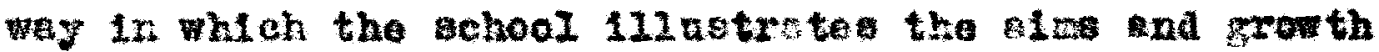
of rocntionol educktion.

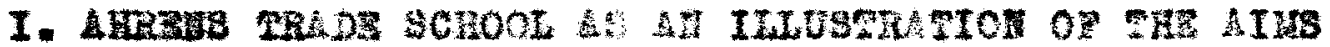
OP VOCA

Insanch Theodore Ahrens Srade Sohool carriod out the alad of the rentucky progral of vootionel education-mith bat s sagle jor oxception-1t might be well to notloe what those alas aro. The exception wontlanod is in the case of agriealtural aduction, which Io sonewhat entside the prortnee of khrens, slace the 
10tter io a clty sohool and priasily interested in the training of elty chludren.

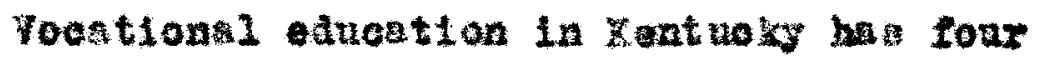
general dvislons--agrionltarel eduotion, trade and industrial dneation, how oconomies etuention, snd Alstributive ocoupatione eduention. Feh of these has ade continuod and sutatential ghins in aberulnese and

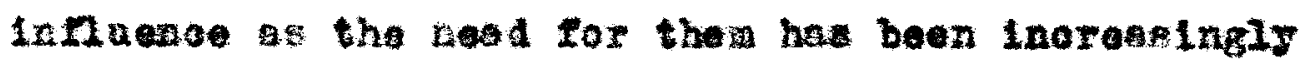
dononotrated.

Foostional eduostion in agrieulture includes planned lnetruction for al-day paplis in hlgh sohool

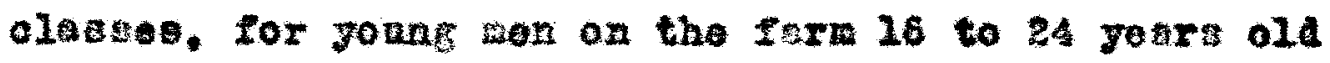
in part tise alesses, and for adplt farsors in orening

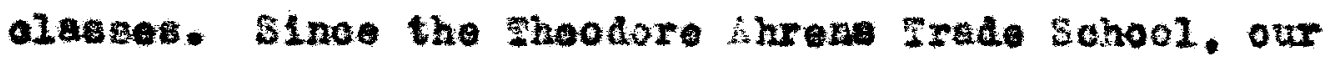
maln point of interat in this atudy. does not tenoh syrioulture for roseono alrezdy observed, it is ouffiolent meraly to mention thic subjeot as a part of the otete "o prograge she other three alvisione exe treated below, and 1 will be seen how esch of them oocuples inportant plece in the coure of inatruction De threne srade school.

The groups Borved by zantucky' program of

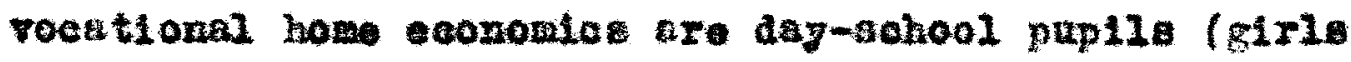
and boyel, out-of-Eehool youth, and alta. The work For och group 10 brat on the nede and Intereste of 
the groap es doternined by oareful anroge of homos and conanity. 1

In rootionel howe economico shrend provides the usuad traluing In cowing and cooking with wany interestlug variatlons. Hillnery, for examplo, 18 avollable not only to regular papila but slao to older girle who doniro to lenrn a trade. Those girlo 800. handle, and work with attrsetive gateriala which they turn into equelig attrsotive, prectlcel products. Boking clastes. too, hare arswn number of gtudents, inoluaing employeo of boker $104^{2}$

The attention of the state progran to distributive occupations ie also followed by Mrens srade Sobool. Distributive occupntions are those followed by zorkers alreotly onghged in morohandising cetivitles, or in alreot contact 1 th buyorg and sellors when (e) dstributing to conaurerd, rotallers, jobbers. woleselers, and othere. the products of ferm and Inanetry; (b) managing. operating. or conducting a oomercial service or perconel service bualneag, or selling the services of etch buctnese.

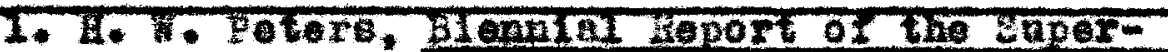

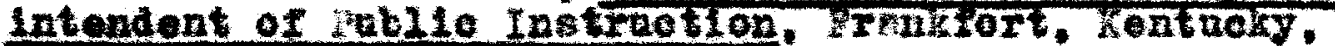
Jun 30, 1939. p. 130.

2. See pege 85 of this thesio.
} 
Bareation for those ongeged in the alstributive ocorpation 18 new phas of the atete-aide program of voostlonal edueation. The plan we inaugarated only after the begiming of the oohool yesr 1937-38. Daring 1933-29. however, more than 1.100 persons have been enrolled in olosee in distibutive oocnpetione trronghout the etate. The program is denigned to neet the neede of two gronpe: P1ret, evening olester for adult workers in retall or wholesni bubines: second. oooperetive ay progrsme to train Migh cobool bogs and girle for fore cerrice vork. 3

Distribntive occupntione are preparad for at Ihren in tho contse on baleomanohip sud related studies. Praining is gren in the following branohes: tore organization, store syotem, etady of zerchanass, atudy of different types of custonero and store service. proctloe work in selling is roguired of atudente whilo at111 In cohool. Fis is seonred in tro wayom-in the seles room in the sohool, and in the difrarent departient storos in the ofty. where anager ake arrangeante for the tudente to do part-tine and spoolal seles work. The

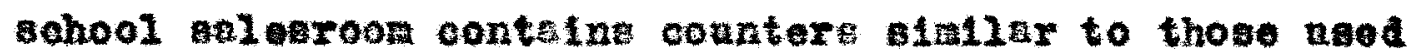
in retall stores, and efrort he been medo tonder the Juno 31, 1989 , P. I84. 
project wore protieal then theoretiond. Whon Fonrth Avenue ceportient atore he relt the nead of better trained help. they have eppenied to hhrens, and groupe of firl aproyen, relenged from thelr daties in the atores for oouplo of hour and ing alact pertod of tho day, have taken cournoe in oaloguanohip. The third and flral aspect of zentrokg's voontionsl eduegtion progran is aleo on with which ahreno 16 vitelly conerned. Frnde fad inenetrinl odnontion, ae the name 1 aplies, has to do with prepering people to ongege in trades and Industrioe. Frode and Indnstrial eduestion of rers the following types of treining or Lastruotion:

1. pre-emiogmont tralning to persons 14 to 18 yenre 011 tho expeot to enter the lield of troder and inatetrios. This type or arrice to youth 18 known (1) the al-genersi induetriel bohool or c)aระ.

2. Supplonon tary, preparatory, or cooperetive part4 ine Inetruotion to persons 14 to 18 yeart old tho have entered upon emplogment. The throo zinde of schools or elasese in this alvieton are:

(I) the trode prepartetory, (2) the trede-extension, (3) the general oentinnetion cohool or elest, the tine belng a emall at 244 hourg yoer or as woh Qe 540 hour sear, depending on the type of organization and typo of setap. The latter is known as cooperative pert-tine achool or close.

3. Supplementery related inforation to enployed pereons 16 years old and over tho sugy find it nost conventent to eoer eveh instruotion in tho ovening or othor houre when not work.

she Indastriel oduotion progrea ia governed by 
cortain rogulatlong et forth in a stato plan for Foostionis Sanotion. Inder these regulftions:

1. All clabes are aet up below college level.

2. They are under publle supervicton and control.

3. The courses of etucy aro sple end prictlesl for the purpose and types of inetruetion intended.

4. The 20081 ooment ty shares in the oot of inotruction.

b. The tescher is a preotleal pereon choeen fros the Indutry.

6. Suah teschers are trained for the fot of tenching betore or anring the first yeare of corvice.

In the story of theotore Ahrene Frade sohool. gathorod frow the feots which follow this chapter. it 111 be ceen thet the sehool fully weote oll thoee regulations in ito attue ne an inatitation of roegtional odrection. The Ilnes imedately followiag, horrorer, will ouffice to ladicate more brieng the maner in whioh Ahrene fwalle the partionler aid of the gtete progren.

Frode and Industridel edvestion aro provided for In the collowing types of rk: ogtinot, achine, sheot

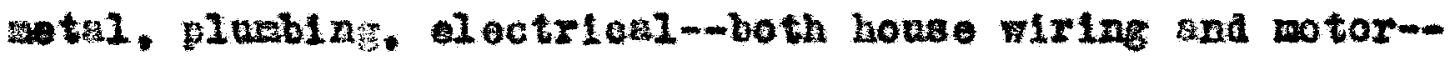

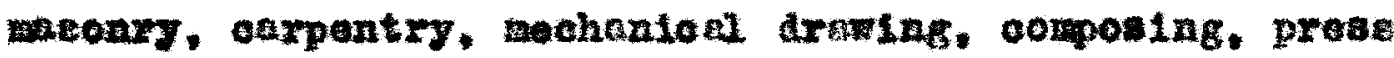
room, bindery, to. Hodel fatory conaltions have boen earried ont in the oonstruction of the veriove chops. 


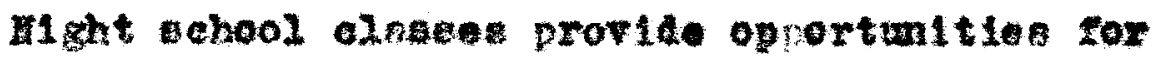
thoge niresdy out of cehool and omployed who, howster. noed farther latraction. Clnges for fonrwoymon

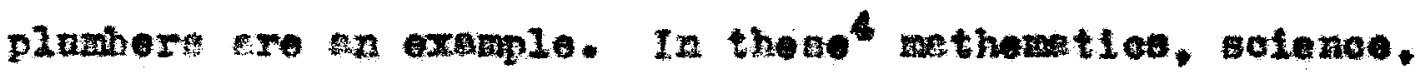
and ehop araming are abjeote covered, wh practioal work in problens of the trade. Drawnge ere de and complete layonte in plabing fixtares are shetohed. The foregolng facte are not intended to provide a complete secont of the conraes and ativitise of Thoodore Shrons prede Bohool. They are here tontioned werely to polnt ont how the eahool earries ont three ne jor atre of the rentueky plati for statemide vocftional -ducation-mareig, home coonomiar, distribntive occapations, and trede and industritl edection. In acoordance Why the purpose expresad at the begiming of this ohepter, the two sections following decortbe the background for Ahrene Frede Sohool-- the genersi acheme of

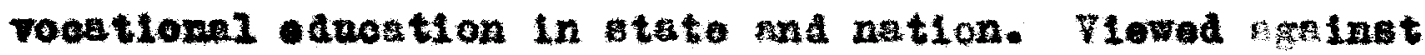
thie bickground threns my be geen in truer perepective.

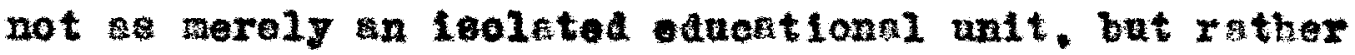

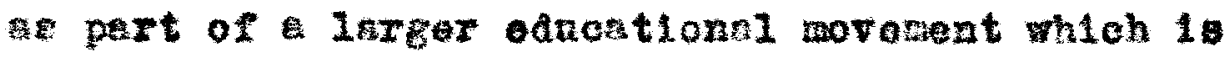
steadily gaining in inflaence and wontar.

IT. THX pothese OR VOCA Aperiad todeg is one of the forenoet of Indectrial 4. 300 pago 86 ar ThI Tetr. 


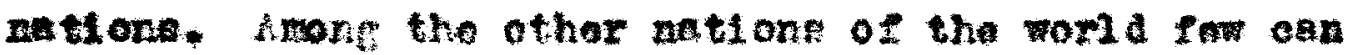
compte rith it in the quantity and andsity of Indnotrial products. Pven e Iter the dobostle wante have been satio-

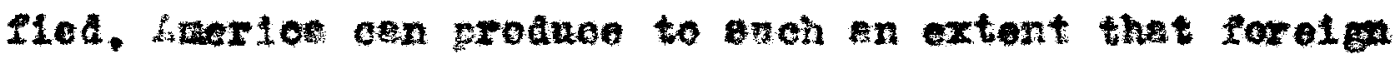
andice te cen be eupplied, if not doratnatad.5

Haturelly. tremendous changes have nocompanted Ameriod's riso to thie poltion of induatrial pomer. During the four and one-half centurien alnce 1492 our oountry ho ratoho s place conpreble, if not ouperior to that hele by the wore advaned of the natlona of Europe. These changes have been folt in ell opheres of Anorice's notivities. Indastry, polltios, raligian.

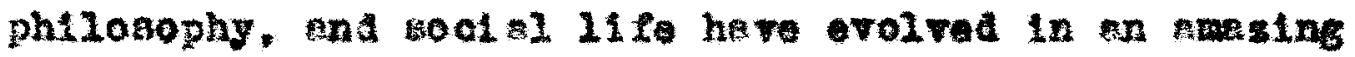
manex. It 1 heraly to bo wondered, then thet eduction hav also falt and ranoeted the lipact of this raple nations I Aevalopent:

The ohanger in oduestion heve been doeply rooted In the chages in laduetriti 1 ifo and colentitio twoght. . . Fhe fiet thet the person mat be wage enmer, fact often overlooked by acadenic

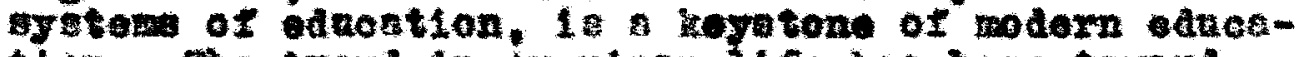
tion. The trond in twarioan iffo has boen towerd Industrialism, conequentiy the trend in eduostign hes been toward tralaing in Industriol paronite.6

Eentucky. 11ke other etates of the Inion, has ondectored to keep pace wth this groking nead for

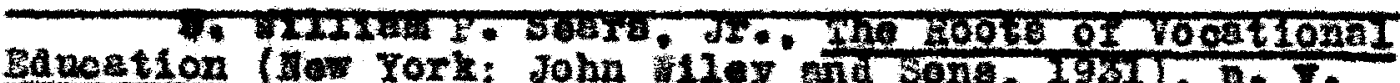

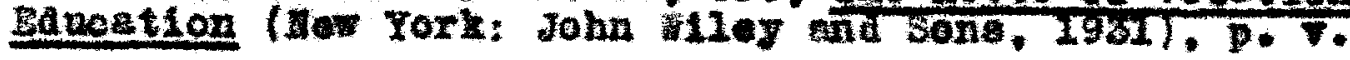

6. Ibie., p. v, 1 . 
roontionel eduction. I. H. 繁0ode, state Direotor of

the Divtalon of Voontional ganotion. has expresed

the goal of his department in the following worde:

Tocetionel education in Tentuaky in on integral part of the public school oyotem The roontional ald If by no mane the oxiy ala of ednetion. We In rocational educetion realize there are other outetending alas of odvestion that relate to the rundamentai cotipitiea of oar prosent-day IIf., w thont the ald of whoh rooationel eduostion oould not sceomilisi $t$ to purpores.

Vootional ecuetion la not of one klnd or of one procedure. Thovgh treining for a seolfic voestlon or stoup of vosetions, it has tor gouth

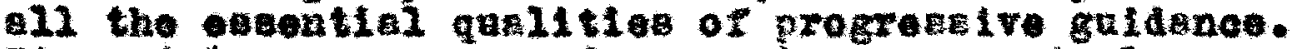

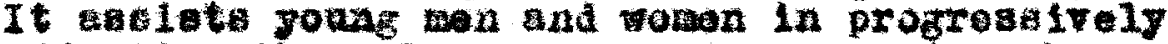
ajusting themelves to roottione. It would be

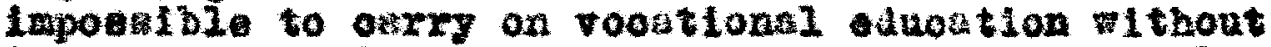

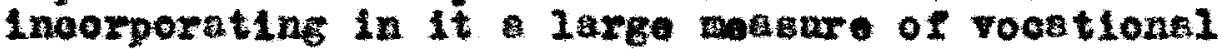
culdanoe. Yoadional odnotion loes not cose whon youthe leave the dey cohool, but oftore continuing edneation through ita prrs-time and ovening conrees

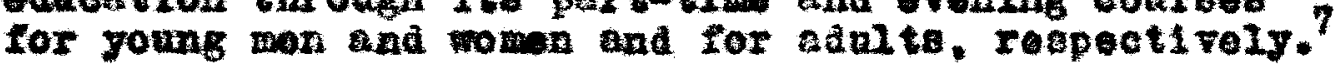

The Ilrat roostlonal ducstion bolow college level

in rentacky, under ang of tho Poderal sote. was in 1927. the smith-fughes at having been pased in gobrutiry of that joar. Whus the Furet ennanl reporte to the Fentuoly Diviaton of Vocktional aluation were for the school jear of 1917-16.8

In 1918, the Division of Voctional Bduotion in

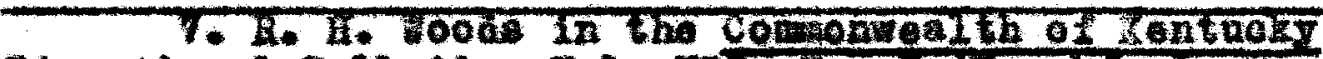

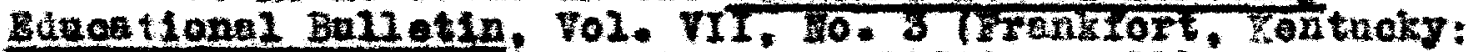
Btate Departront of

8. H. Petera, Ibld., p. 110 . 
the State Departaent of Ednation was eqtablishod and a spervisor of Vocetional hgrleultare was appolnted.

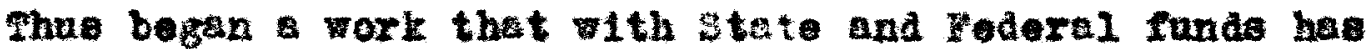
expended Into e eervlce brond in scope.

The state High Sohool Inspeotor in his report

for the year ending June 30,1919 , hed this to bay:

The state Boara for Voontional sacetion, soon a it we organised, designated the university of Zentuaky to tralning sohool for white tecohore and the sentucky rormal and Indugtrinl Inotitnte the training school for colored teecher destring to equip themelves for any one of the three roeatlons Indiog ted in the sul th-Bughes 2aw. Elght Bchoolo epplied to the Board for the privilege of eatnbilehing Sal th-ghghes work in voentlonel Bgrloultare zor the remelnder of the sehool year ending Jene $30,1910$. Six of those vehoola qualifled and were relmburiod. Three or tour chools qublirled for work in rooational home coonomies at the geme tine, end two tor trades End Induetries. For the sohool year endif jone 30 . 1919, tonty-three bohools qualifted for work in fol th-lighee roentionnl agrionitare, twelve in rocetiongl hom conomies and tro schoole ror ror in stalth-Hughes rootional tridee end industries.9

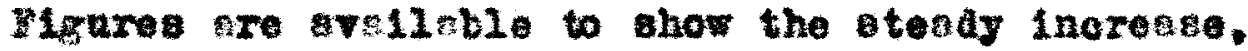

In recent youra, in the nutber of gtudents attending trade and induetriel clesees in rentucky. These. Indiosted below, oover the four yeer perlod from 1935 to $1989: 10$

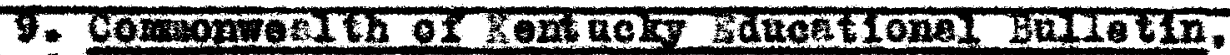
publ lahed by tho Kentwocy Departirent of Eatiostion, rrankfort, fentucky, Volume VI, Ho. 10, Decenber, 1939. pp. $22-83$.

20. H. Petere, Blennial Report of the superintendent of gublio Inetrrotion, Prankrort, Zentiox, Jate $30,1989,0.49$. 


\begin{tabular}{|c|c|c|c|c|}
\hline Bohool Year & $\begin{array}{c}\text { Dey-irado } \\
\text { c1abees }\end{array}$ & $\begin{array}{c}\text { part-mue } \\
\text { c1andes }\end{array}$ & $\begin{array}{l}\text { Svantus } \\
\text { clases: }\end{array}$ & nota \\
\hline $\begin{array}{l}1935-1936 \\
1930-1987 \\
1937-1988 \\
1958-1939\end{array}$ & $\begin{array}{l}1,201 \\
1,276 \\
\frac{1}{2}, 614 \\
2.210\end{array}$ & $\begin{array}{l}1.171 \\
1.777 \\
1.837 \\
1.866\end{array}$ & $\begin{array}{l}473 \\
177 \\
747 \\
950\end{array}$ & $\begin{array}{l}2.924 \\
3.230 \\
3.798 \\
5.025\end{array}$ \\
\hline
\end{tabular}

Dering the came period the jor derelopwente in trede end laduetrial educetion were the establishment of centralied rocetional sohoole, pert-tiwe prograne In ecellenoone occupetions, and arening extenoion tralning. To state roontlonn schoole were otablished; one for whte students, tho rtyo state Vootional school at panterille. and the other for negroes, the weet rentuoky state Vooatlongl praining sohool at grdncoh. Contral zontnoky had potential centrallsed roontlonal bohool vith the opening in 2939 of tredec depertment at the Lafryotio wigh School in Fayette Cownty. 11

Loufevillo, of course, la large onough to mien atudent for orery Cepartment of etudy in 1 te khrene

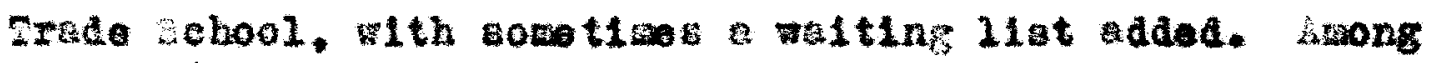
the amer towne however, several comentitea have instituted cooperative part-t1mo olagees in stroelloneone Dconpation to give occupntional tralning to etudents of 
high school age in the oocupetion ovilable in the cownenty. It is imposelble to at apops in a gchool for Euch occep lons are cerried on in a sanll town. Shere aro not enough poople mploged at ench trade in any one year to wrrant a olas. Therefor e. cooperative arrangeraent is wade between achool. and comserelal chope thereby the lesmer or apprentice eqquires the billis on the job and the related technion intormation in the sohool. Fime is aleo arrnnged for the etudent to comple to the regalar high school sub jeote nocesary for Groduntion. 12

Shese Fetr frout rocetiond oducation in

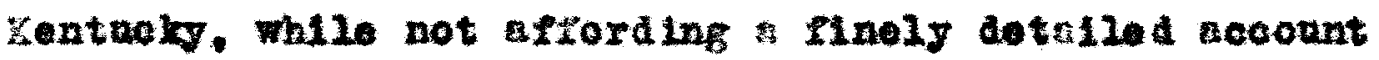
of it progrem, do neverthelese preent the rrasework of the tate plan into ahioh the cheodore Ahrone srade

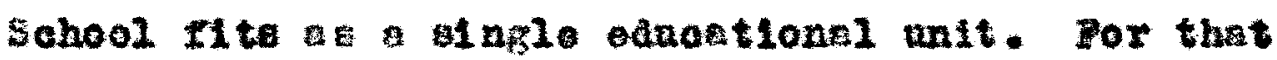
reason their inoluaion has been considered relerent to the preeent alsonesion. In turn, rocktionel edvention Bs natlonal worement apposze morthy of the same degree or attention. The next rev pagee nre devoted to a brief ravien of $1 \mathrm{ts}$ development nua progreas. motiver ana has. 


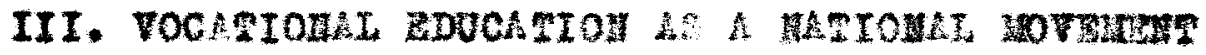

The foundation of rocstionnl edneation in the

Onited stateg has been in the proeese of formation alnee the beginning of thin contnry. Few indeed, aays J. C. Wright, of the 25,000 techars, suporvisore, and adminiatratore now mployed in thie fleld of edneation hed any large part in the laging of the cornor-atone of this edneational struetare, whloh now curolle nore than one milion studente in the publis sehools of our country. 13

Burling the ploneer deye it rav hecests to derelop a phloeophy and fundamental principles of adninistzation that wonld atnad the test of the geark to follow. When the Nationnl Voontional

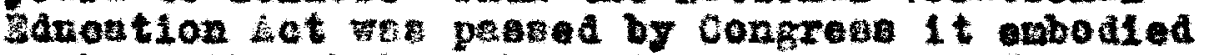
wow of the phitgeophy and experiences of thowe early ploneere. 14

Poday. tosohere, sminlatratore and lay oltizene

alike are interested in the appliontions of tederal

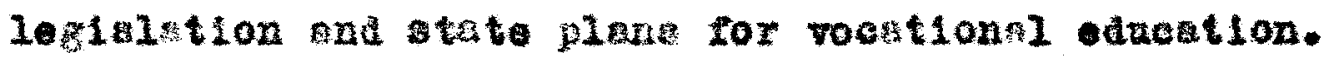
The report of the Dougles Comission. ${ }^{15}$ the ploneer

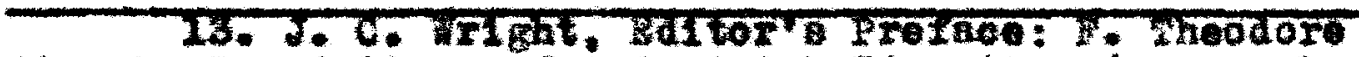
Struok, Goundetione of industrial zdnention frew York: John wiley and sons, 1960), p. XII.

\section{Ibld.}

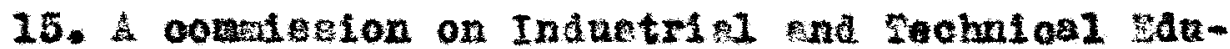
oation was appointed in 1905 by Governor N111an I.

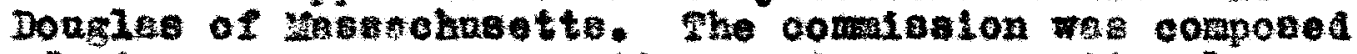
of nine perzone representing varlous occupetional paroults. It purpose was to investiget the need for sduestion in the different erades of gilli and reaponelblilty in the various indestried in the cononweslth. Ibla.. p. 84 . 
work of the Hetionil soctety for the prowotion of Industrial zinostion and the afforts of lator sacelations, all contribute to the theory and pratioe or Industritol education se we know it at the prepent tial. 16 Howerer, the moving force which has brought Indugtrial and trado ancetion into boing is the modern developmont and groelng oomplexity of industry itself.

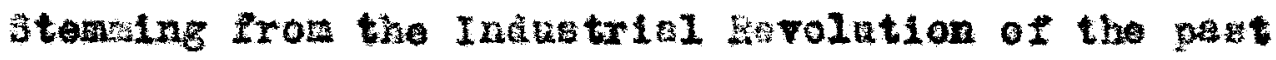
century. the sodern faotory oyten in a jor joot from whioh rocetlonsl educetion has developed. The phases of the Industrial Revolution which ean be considered of mafor infuence include (1) the use of power ariven mohinery in induetry. (2) the alvidon of 1nbor. (3) the shortening of the hour of 2sbor. (4) the inerease in per ceplta mes, (5) the entrenoe of women lato factory labor. (b) the devalopment of cclentitio research in induetry. and ( 7$)$ the problen of lactory mangenat sad coriatetration. 27

Porhepe the wost ortaent ehrnge in indwetry cansed by the Indatrial Revolution we (1) the change from hand production to achine production. This required change in the training of zorkers for

$$
\begin{aligned}
& \text { 16. Ibre. p.x1. } \\
& \text { 17. 1bed. p. } 279 .
\end{aligned}
$$


postlons in induetry. Fo seet the noelde of the now 1nductrles. the privato trede schoole arose. Jany were founded after 1880. These inelnde the rea York prede Sohool (1881), the phlladelphia Bullders" Brohenge (1890), end the Baron de Firech Frade sohool (1891). 18

The division of labor mentioned above (2) as a contributing factor in the development of trade gohoole. refer to the speciallzation of occupations in indutry which bease necencery beoube of the intriotales of modem weohlnery. In order to provide operators akllled In the ves and knowledge of complex and highly apeolalised chinery, the retorios themelves entablahed training sohools. The restibule schoole. the forenenehip tralning programs, and the corportion cohool are oft-ghoots of this lapulse. The schools of the Oeneral dectrie conpany, the rentinghoude Bleotrie company, the Hew York Central ald 1 road, and the Talo sna Fowne sumpleturing Cowpany are conorete oridenee of the fsot that induatry 1 teelf has been vitaly interosted in rooationsl traintug. 19 The rhortening of the hours of labox (3)

$$
\begin{aligned}
& \text { 18. ItrT., p. 280. } \\
& \text { 19. Ib1a.. p. } 261 \text {. }
\end{aligned}
$$


constitates a further root frou wilon roodionel -dneation can be sald to have oprung. Fith the reinotion of honra from fourteen to elght par day 1 t beouse erident that Forkers conld engage in zurther oducation anring their epere time. The firet effortB to provide such opportunitles were elong the lines of evening choole lneluatac. anong othors, thoe condueted by rnrious olties, the Joung ien's chriatian kseoclation, and by the foctoriee themselveo. These esrly evening schools atterated to orry on the general edncation of their atudenta, while thoe of todey have widenod thalr cope so of to include, in addition. opecialized courses of voontional charmetor. 20 Another feetre of the preaent industrial egotem is (4) the higher wage pald to indutrial workere. Phis is a seano by mioh Indivian workere way eek further education. The How school for foclal Beeearch in Hew York City. the trade extenelon sehoole, and the ovening and part-tin onglueoring colleges throughout the conntry ere institutions which oster to the neede of the wore aflivent forkars.21

The ontrance of towen into Ladutrg (5) has

20. I0Ia.

21. Ib1a.. p. 282. 
Intenelifed the problem of laduetrial training. The

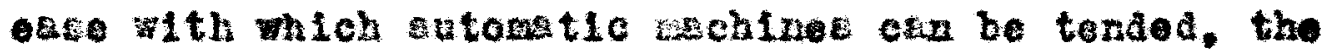
ohort houre of 1abor, and tho tempting wge have been inetrumental footors in luring wowen into the factorles. The Inotory sehoole. the trade sohools, and the oontinuetion schoole have brosdaned their scoper to to Inelade froilitie for the training of women. The Wanattan wrade school for olris and the Boston Frade School for girls, anong others, are the result of women" Gdvent lato Industry. 22

Soleatiflo rosoarch in indastry (6) hns creatod the ienan for research forkere both of collego and sab-00110ge grado for post tons in fadustry. The birth of wodern eclenos can be traced bnok to the retionalLotic arn shich occurrsa about the the of the prench hevolution. After that the, howover, selenee took a new tark. The influence wet away from pure and theoretion studies, and toward the lelds of enginoering and applied uol moe. The Amartenn oolleges ware not alow in oosing that the direotive agents for the Induetrial worla must be toohnieally trained experte. Anter the thira quarter of the nineteenth centary engineering sohools grew up throgghout the country. For rasebroh porker of lese than collego grades. 
funter researoh workere eo-called, the faotory ehoola

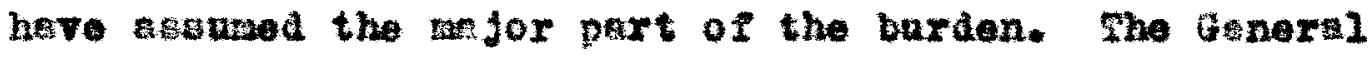
Electrio sohool 18 fine oxample of this type of Inst1 tution. 23

The problem of fnctory magement and adminletration (7) hae been cared for largoly by the collegea of engineering of the fultod states in their depertmenta of Industrial engineering. The Jnivercity of louinville, the Jnivereity of cinolnusti. Jen Jork univereity and the coorgla Fechnical Inetitute are exapplea of the many orgineering chools which have attented to supply Industry' demand for losder of abi21ty and training. The schools Eentioned realised the ahortoominge of thooretieal traluing and have carried on their work by wosns of the cooperative agater of training. The strdents opend their tire between the school and the shope, etudying ander oollege conditions, and working on real jobs in true rnotory atmoephere. 24

Leg1aletion. both national and atete, hese been

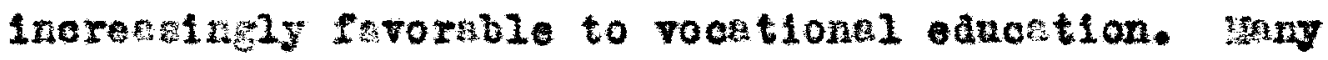
ageneten have jolnod in the demand for podarel ald. Fo santion the most prominent caspelaners one mast lnclude

23. DET: D. E85.

24. Ibla. 
Industry, 1abor, the onglneering sooleties, the fratermal acooletione, duostora, parenta, Industrial workere. and boelal workers. The result was the paresge In 1917 of the smith-Fughes Aot and the creation of the Foderal Board For Foestlonal Bdnation. The reeults of this plece of legigletion have been the Lmproving and developing of conntlews roostional schoole. The 1930 report to congrase of the Pederel Besrd for Vooetlonal sducation states that there are $1,066,000$ pup11s onrolled in rooational courees approved by the Pederal Boara. 25

Vocational etuestion has to-day becoms \& vital part of tho training necesenry to fit goung peoplo for IIIe in an lnoregelngly complex age:

- - In a coclety sech ab oure, baked upon an Industrial oconom wheroby the grester portion of the popal tion engages in parsu to of an Induetrial. oomerefal. ogricaltural. or profeselonal nature. it is reneonoblo to expect that the public sohoola, the groat foroes of goclal control. W11 assube the reaponelbility for tralaing theeg people. for thelf plece in the soolal etructure, 26

The sheodore hrene Frade sohool in en interesting example of the answer evolved by smerican public schools to theet these expectations. In the precoding pages it has been regarded as anit in atate progrem.

E5. IfC.: P. 290.

26. 1010. 
28 single expression of a nationsi moremont. In the pager to follon it is to be looked apon at an individual inotitution, and ite hietory, charfeter, and commity infuence, carefully axamod. 


\section{CHAPTEN II}

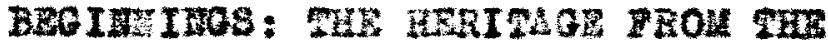

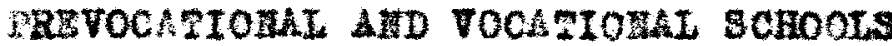

The gchool now known os the Theodore knrens Frace Sohool wes in exiatence more thon a decade betore the expantion which accoupanied $3 x$. Ahrens" Ilnanolal Birt late in 1924. It was octriblohed in 1913 and wae colled flret the prevoentlonel school. After the introductory jeara of 1 ts career the nra was changed to the Joulevilie Vochtional sohool. Ey the latter

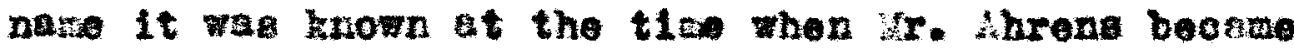
awere of it poselolities and deolded to enlarge the scope of ite oervion.

In the Lonistille vocationsl school the ofty of Loulsrille found a ready do foundation for the Theodore ihrene srade sohool. The istter is referred to a en ontrow th of the Vooationel sehool with complete acouracy. It inhorited from its predeceesor a principel. 1 a belialng eite, and a large proportion of

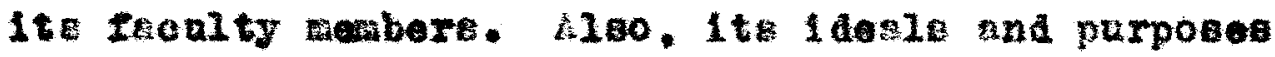
were doreloped slang the sewe Ilnee that the Vocetionel sohool hed followed. 畨1 th thic relationahip in alnd. 
the reagone for digensalng the frevocstionnl and 7ocetlonsl tohools bocomo aleor.

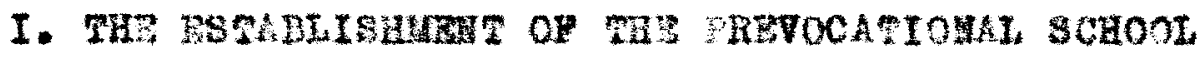

In the Pirgt Repart of the Lonieville Boord of IAnoation, oovering the period from Janungy 1. 1011. to Julg 1. 1912. the neods of the Louigrille sobool syatem ere 11 sted. 2 shere were treive noods citod. and of those the ofghth wes "the establighent of a teohales or vocetlonal ingh sehool." Through the

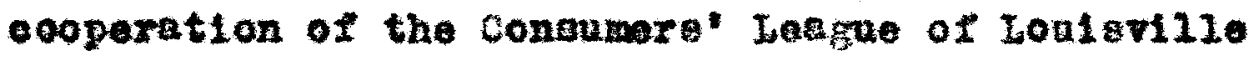
the year 1913 en the first steps taken to noot this noed. The 1aportwnes of the role played by the Conenwers" Lagne will presently recelve due conolderation. It wae the initiative and energy diplayed by thet orgenization whioh zere pridurily responstble for the organization of the erevocetlonel school.

The Erevocatlonal sohool opened in 1913 at the Walson streot school, Seventeenth and Madicon streets. itr. Lom $\mathrm{F}$. Brom in Hie the 818 . The Hetory of the Pablic Secondnxy Sohoole in Lonieville, Fentuckr. given the following gketoh or its oeriy cotiritios:

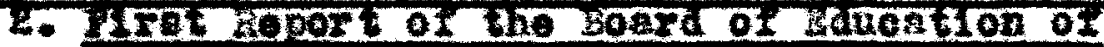

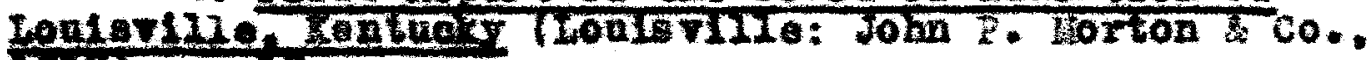
1981. . 20.
} 
Whet is now the meodore Ahrens prede Sohool had Ito beginning in the Frevoontional sobool that wa organized in 1923 at the Iadison Stroet School to weet the nesd of aome Beron hunared to one thoueand puplls who were leaving sohool overy Jear et the nge of twelve. The parpoe of the bohool whe three-fold. Piret. It was to ground the pup11 in the fundamentale of an acedemio educetion. Second, It ves to give him an ineight Into severel trades and occupations. Mhird. it was to help his to choose roestion wiselg. So acoomplish these three parpoes the following were Ineladed in the course of etudy: printing. drawtng, book-binding, woodwork, weohnnioel drawing. practical arit heotic, Bpelilng. history. and oomserolal geography. The twenty-one bogs and eloven girle who enrolled the fir at your were tanght by one cendente teecher who was pald by the Bonrd of sancaition, and one ghop tencher who we pald by the Lonidille Conenmere Ieague.

The following septedber, the school we noved to the annex of the dralnietration Butlaing on Elghth street. The school oovered so thoronghly the aeventh and olghth grade course of etudy that efter the completion of two years wor in the prevoestionsl school, shy boy or girl conld be recormendad to the regular sentor 1 in school of the olty. This often happened for sany of the boys end tris renewed $t^{2}$ liking for sohool and wore cosirove of continuing their studies.

In 2915 the eohool agin mored, this time to

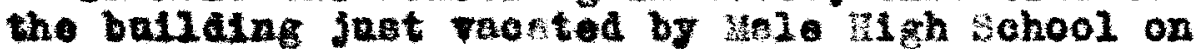
piret street between chectnat nud alnut. It ie otill at this loostion el though the ballding has beon rovedeled and snnexed to 80 moh thet it does not ween to bo the bare bulding.

Boye and frla continued to cono to this school in ench nubbers thot in 1916 it becene necesarry to requiro thos to have finished the $1 \times$ th gredo before they could enter. 3

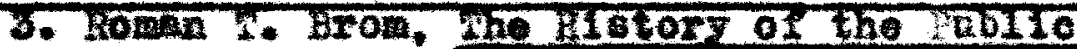

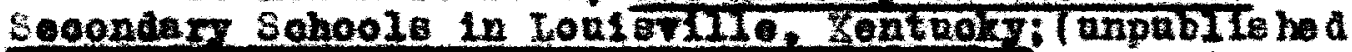

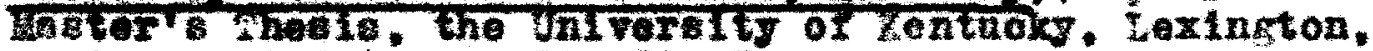
Zentroing, 1938), pp.77,78,79. 
II. SUS COOPDRA

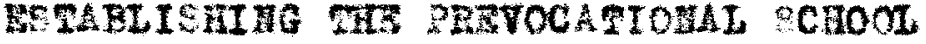

The part ployed by the Consamers' League of Lopisvilie in the oftablishment of the Frevocationnl Sohool hav already been azgerted. Its intereat in Industrinl reform and in proble ouch os child labor naturally lod to conelderation of the need for vocational educstion. In an artielo eopociolig writ ten For the Anniversnry zubber of the Loulsville rlaes. December 31, 1909. helen Lurray jandolph deacribes the beginninge of the Consuners' Lesigue nnd its efme as follows:

Deatined to work cone striking retor we, and to enlist the latelligent cooperation of the grat aray of wowan shoppers, the Kentucky consumers" Leagne was eatablished in 1900. Its prisary object was to ieprove cond tione among the garwent makers. to bolish in oo tar as poselble the "awest-ghop" gyz tea, and to have appolnted fnetory Inspector to insure 11 ght and anitary conditions for the zers of all etituhed garments. Whis reform has been helped slong by the Incrensed demsnd of "congunere" that gerrente purohesed by thes in the atores besr "the Consumars" Loegue 18bel."

Fille the firet onergles of the league were dirocted toward this ond, lnevitubly other noeded reforne which oould best be bronght about by the wowen who purohaded the garpente and who wore cerved by varloue elespeople have been accompli ahad.

- Then more ooprobeneive la Elaletion looking to compaluory ecucation and child labor we pased, the leagre vorked in ha mony with the 
truent officers and cared for the ehild while it attended school. Leoentig the child labor aecociation hso thien orer this branch of the work of the Consubers' League. but previous to that t1 the consumers" Langue oarod Igr ninoteen chlldren and expended sore then $31,000.4$

wether or not it whe the initinl problem of truency conpled with chlla labor which tarnea the alnd of the conoumere League tomer the need for Industrial ednestion, cotion toward that ond wa not $20 n g$ delayed. The outline of work of the consumera' Lagtie of zontuoky. 210ting ite in ecouplishments from ita boglnning in 1900 to the your 1924, notes that in the p rlod 1902-4 the Leegue cabited in pasaing the child labor Lar and the Cospulsory gucation Jin and anending thes st man seatons of the Legislature. It ooopernted, 1906-8. In onfor olng both, by working with the truent offleerd. Fielting the howes of truente, and explying thoe and clothing necesesy to roturn them to eobool. The outilne notes, farther dow the Ifet, its responelbility for tho IIrat pocetionel school in Loulgrille fire yenre later, after ef ght wonthe of preliminsry work in selooting an inetructor and vis itine sany eitieg for Informetion regarding anoh schools.b

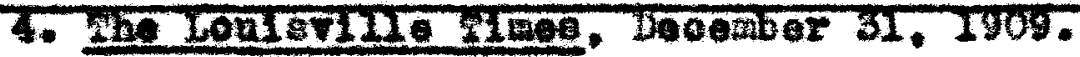

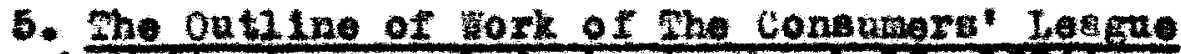

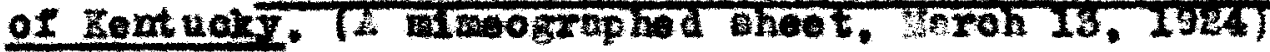


The prrtionlar interests which oarried the

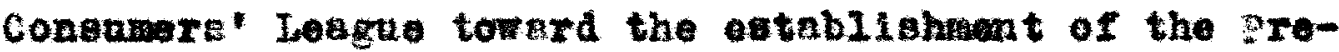
rooetlonal sehool are reheoted in exerpte frow the

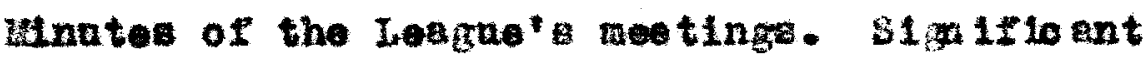
exaaples of these rollow below:

Cetober 27.1910

Sereral onfgetions were wde and diconsed-nomely--Thnt in opring, nerchante be roguested to pay not lese than ${ }^{6} 6$ to gir 1810 and over.

The Louleville neede echool for troining cierzo.

That weyohant be abed to out ilne courees of training and have this work handied by tho Loulevilio Bnstrese women' c1ab.

Hra. Helleek was athorlzed to ooneult othere wering elong the Ilneg of Induetring work. ...6

Annusl Yoet1ng, Devetaber 6. 1910

a nes conaltiee onlled comaltee on Industrial Haveston was desided apon and ire. J. B. Jadah appointed chas rwen. . .

Bosrd weoting, Febraty 7, 1911

As the suat nees toman's club la planning to take up all kinds of eduostional work, and one branoh io to come under the hond of induetrial trolning--and

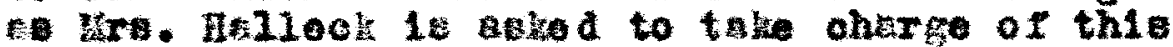
branch--the asiod for volunteers to Berte on her

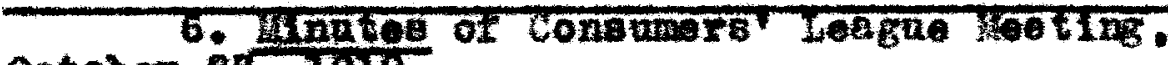
Detober er. 1910.

7. Ibld.. Deoamber 6, 1910. 
oonattoe ent res entipte to heve it compoged of nomber ot the constuere Jeagne our prenent noed stetod va to svo chilaren between 14 and 16 years of bge-who got permite--bome preparation by lot loget fow reeke troining. which pate tho in position to demand botter wagea.

The vense of the Doerd wa thet it wonld like to undertake the work in oonmeotion wth the

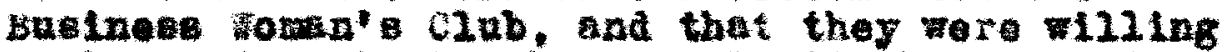
to leave detella in the Irosident's hande co to retion to be take before the next gaeting. . .

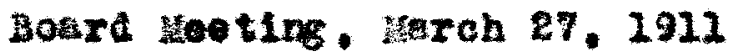

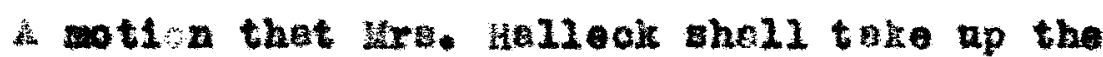
Induetrial work in commection with the 3inelness 篗 onan'e clab ras ofrried.

There wero recomendations following alsougs ion of this work to the effect thet sil aldetes of

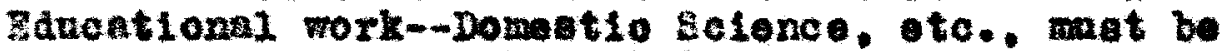
on the sum bas 18-algo that ponestic solonce as well es salenansho be inatalled tonoe the Bublnoss woman' club. ...9

called veoting. Seroh 20,1913

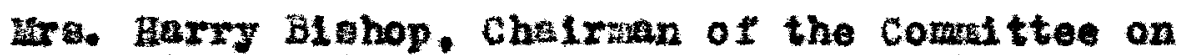

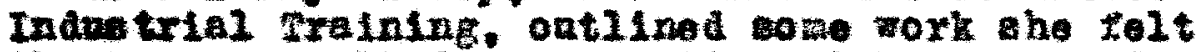
the Leage could do cooperative with the Botrd of

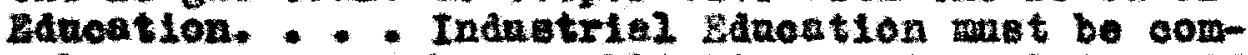
puleoxy and ast have pabliaty and legielation it pare 1b1e. . . 10

Board waeting. 4pri1 15, 1913

The Chalman of the Induetrid Irelalng condtteo. Lra. Blohop. atated that the bullalng of tho Doard

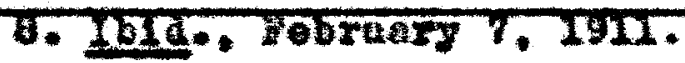

9. Ib14., wareh $87,1911$.

10. Ibla.. Meroh $20,1913$. 
of Batucation hat foux (4) racart rooms that any bo wed by certaln number of children on the polnt of leaving bohool. gi ring then industrial tralning by akilled industrial tenchera. Sugfested

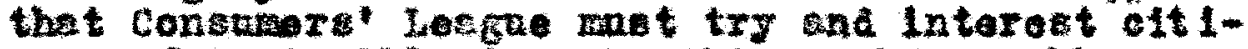

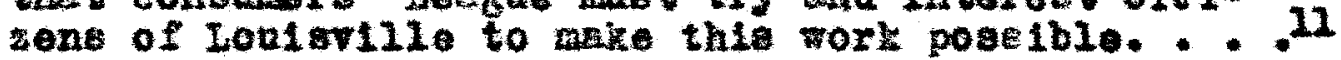

Bosrd Leeting, Ootober 10, 1913

13re. Harxy Bishop, Chalran of the Induetrial comaltee reported the eucoessful lavnohlng of the Erevocetionel chool, under the jolnt areploos of the Consumert" Lesgae and the 3ogrd of Eduontion. of the 2,000 necessary to finnce the undertsking for o year. 12,000 is in hend, the two teschers

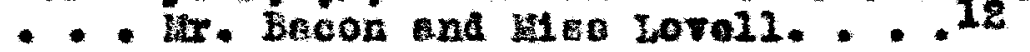

This record clearly indiestes the oontinuone and onergetic efforts of the Consurara treatue flong educetional 21nes, Plnelly resulting in the opening of the Prevocutionel school. Hawever, the recorde of

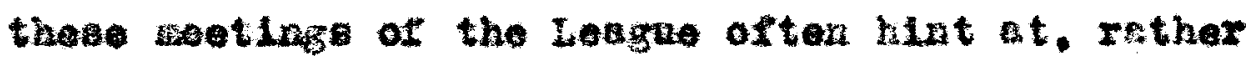
then acturily reveal, the real notivity alrected tomerd the counding of the new oohool. Sore detelled informtion 12 sound in the printed progren need st the dodiontion excrateos of the theodore Abrens prode school, and nee is ade of this Informtion in paragraphs 1 radiately axceeoding.

The Induetrial Bduection Camalttee of the conBumere" League wes the minspring of that organigation's

2. IDE* AprII 15. 1913.

12. Ibld.. Ootober 10, 1913. 
-ducationel effort. This condttee's moril wes motirated by the foeling that there ter an urgent noed for spocifle trining of the young worker. such tralning. It we held, would gtve hiz o ereater veluo to Induatry, to soclety and to himeelf. "Groater -Irloleney before asking higher wag" beand the slogin of the Indastrial Bdacstion Comattee. This conmet tee, under the ohe1rmanhip of

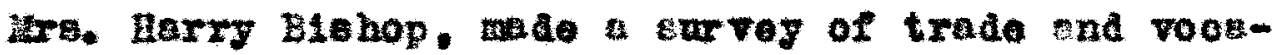

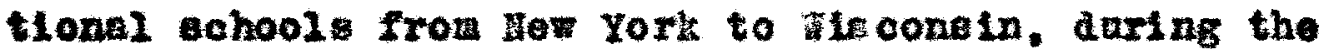
period when founalng of the pretocetional school was belng preparad for. An advieor. Frank wtohell

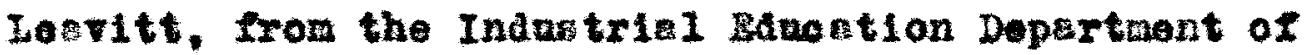
the Uniteralty of chlongo, wa brought to Louleville to surveg the oouculty and make recomendations concerming course to be of fered. after etudy and consideration. plans were devaloped for a very amsl1 beginning. is definite in controlled these plane: the tralning for a pecillo trade with cerefully correlated acedentc onbjects.

By perwigetion of the bonrd of rduction, the children to receive tralning durlag the firet year of the ahool't extetence ${ }^{13}$ were solected by the consurera' 
Longee comattee. Thear young people hed to be fourteen years of age ond over, and ca par advaroed

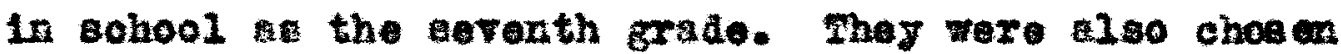
for thatr interest in an early ontrunce into wagoarning obeapations. In order to obtain papils fulflling these quallfleatlons, name of chlldren who had expressod a deafro to leevo wohool and go to work were secured. jang hones in 321 perte of the oity were vielted before the Ilnal group was forded. mirty two bege and girle compoed the int tiel clase. 14

The Bourd of Eduetion sleo allowed the Conenaers' Ieague comittee to belo ot the terchers to be aselgned to the sehool. $\mathrm{kr}$. Louly A. Becon, at

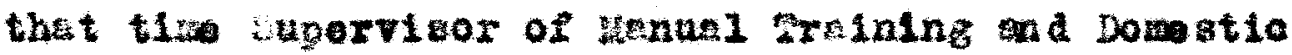
Solence in the Louls 11 le sohool Syoter. Was polected for the shop executive at a sary of $\$ 2500$, pala by the Coneumere' Leggue. Deckuse of her attitede townd -anotion and her contaot with other oducationel exportaenta. ${ }^{15}$ ules Ithal is. Lovell was chosen ne the other Ins truotor.

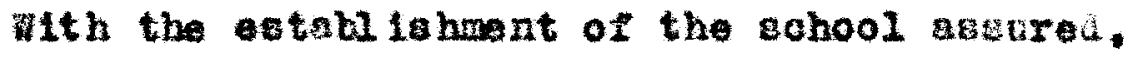
the interest of the Conbumers Lesgue dia not leasen;

16. Hora. The number of athdente vae donora the following year.

15. See pazes $\mathrm{v1}, \mathrm{V11}$. 
there ere ceveral forther Indicetions to the contry The importance of that interent it hat been the alta of thit section to point ont: Fithont it the beginninge,

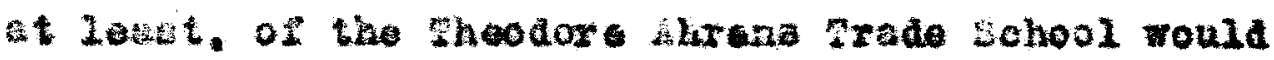
not hare been the sara.

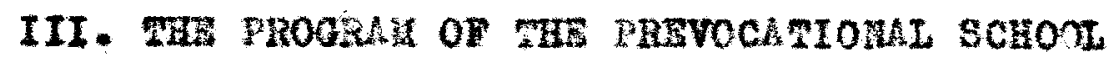

Some 11 ght has been thod on the pien and parpores of this school by ar. Brom's remrke quoted in seotion $I$ of this obipter. 16 The roport of 1 t director. Br. Bocon. In the geoond leport of the Eosra of zurcation ${ }^{27}$ furnishes adaltional fncte. Il profaces his ceoount of oxplalning the seloction of the chool" orizingl locetion at the jestern Departmental sohool. Soventeouth and Madeon streets. A good ang ohllaren in this nelghborhood hed ppllod Tor lebor cortiflaten and been refuged becave or their fallare to present atfifectory proofe of nge or geholarghip. It we felt thet enoh chilaren would be In 8 poetion to aprecinte the froilitles that

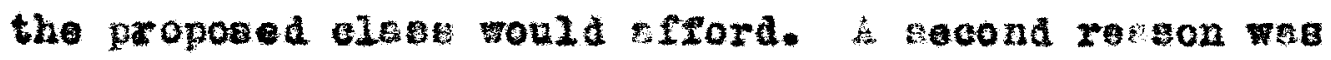

\footnotetext{
16. 800 page 23.

17. Second heport of the soard of zancetion of

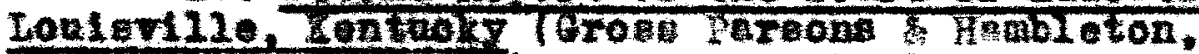
Jourevill, Kantuaky), prow July 1, 1912 to june 30 . 1913. pp. 62-68.
} 
that there wore two roome avallable at 筑e日tern DepsrtEental shool whlch could bo prepared for nes at iltto expense. Mnsily the anuel tralning ehop oould be put at the disposal of the provoestional clase a part of oach wook.

The purpose of the vori. af stated by itr. Becon, was three-fold: to ground the pupil in the fundarentals

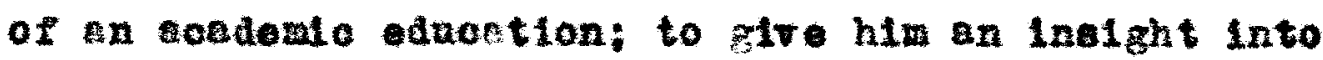
sevar 1 trades ard ocoupetiona; and to help hit to choose witely a roeation.

The currionlaw at this time inoluded printing. book-binding, woodrork and meohantoal drating. prectlool arithnetie, opeling, hiatory and coawerolal geography. During the woek ono-half the tial was apent in the shop, the other helf in the olmseroon. The reguisr ehool honre were oberred but anch voluntary warkes osrried on arter the alose of the sohool.

Attention to bouleville' odneztionel oxperiwant soon spread beyond loosl 1inits. Prank stchell

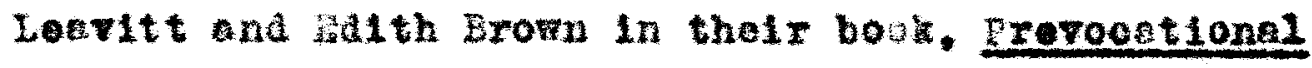
Ednoation in the Fublic tehools, pabllehed in 1915. derote gection to the Lonlevilio gohool. By the tise then they wrote, the achool had alroedy found Alforent guarters in the annex of the Adalnistration 
Sullding ot Blgh the cheatnut streote. A olear oonoeption of ite atatus in this period of its growth esn be geined from their dedeription:

Eighty pupll. Porty girls and Forty boys, oro nccomsodated in the present plant, and thero is a vaiting liat of applicante from whioh reanelos are promptiy flllod. To the printing, bookbinding. and cnbinat-waking have beon sddod electricol viring for boys and trade sewlng tor girle. The printing which incluces coapoeftion, proor-rending and presevork, is opon to both bogs and girle.

The prograsa of the rohool is plenred on a halttiwe ahop gohedule. Fith the other half devoted to condente work which perilleld that of the regular ovrenth and elghth grados.

Groat reodow is given the papile in their oholoe of shop coursoe, and opportunities are provided for geking chenges when any good rongon develope for dolng o. As a resilt thoir laterest In the school 12 go graet that mang puplle romin after flalshing the elghth grade, being anxlons to continue their chosen work 3 e lone es home conditions perwit.

The Bchool is not intended for mentaliy deflolent pup1le. but for those boys and girlo whose elrermetances nnd conditione bre such that they are 11 tely to leste school esrly. A number of ixth-grad puplis tho are thirteon yeare of age have beon adalted for varlone rensons, and for thie partionlar group there 1 al arye on open door. The sterage age of the puplis 18 fourteen years and ol ght wonthe, and the everage grede is the Beventh. she alse of the elesene 18 int ted to sixteen pup118, and the shop inatruetora ${ }^{\text {ith }}$ one exception, are protical trades people. Is

Erocesduge to coment in detall on nore specifle courses of inetruction. the nuthors coment thet much of

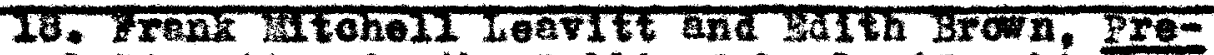

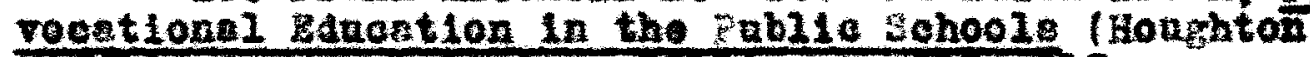
UIfIIn Company, Botton, I9157. pp. 212, 213. 
the vork given is on comarclal basis and all is

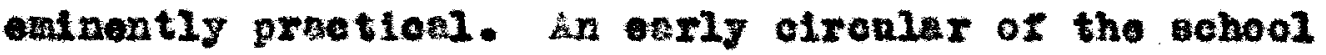

lo qnoted by foevitt and Brom as followe:

Forit hes been aent to the printing clase by the Bonrd of ducotion, the perent-fencher iseoolatlons. Soelal centere. and way philenthrople and civio organisatlons. The vork cone for the Bonra of zancotion and the money receltred from ontride jobe are eredi ted to the class on tho books of the Bosrd of ganction. The following ia pertial list of the jobe done:

perent-Teacher Association notloes, dodzers, tloinete, lotter-heada,

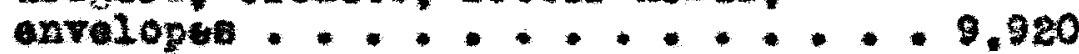
Prind lpal's notioes. . . . . . 3.650 sapervicore" ontilnes or builetine. : 1,250 poara of Bduestion ol ronlara . . . .30,500 Conenmers' League notloes........2,400

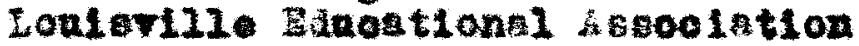
notleer and tleksto $\ldots \ldots . . \ldots, 000$

In IIte monthe. Iron Soptenber to Fobrary 1 . the elase nade 91,600 inprese 10 ne.

At the end of the job, the job envelopes contain copy, proof, revise, preseproot, and finally three ooples of the job. On the wall are timo-carda showlag thoh ohtla's recora upon osch paxt of esch job. proof-ronding is coountwated for the girle. is good prool-rader In Loolavilie nay comand Irom $\$ 15$ to 320 n meok. and many plaoes are filled by women. Bligh npon the velis stands time-010ck, by menne of which the time epent upon och jot is computed by the unit systen in use in zactories.

The printere of the city have taien a gencrous intereet in the sork. a vieiting printer happened to find the shop buty taraing out na order for twenty-6ix thouernd envelopes for the Sahool Children'e Thankeglting pund. The tleo-okra ahowed If fteon bundred onvelopen struok in an hour and a half. the watebasket hored only nine opolied envelopen. This record for time and 
wat to he deelared wowd gtand comparison wh more experlenoed 1 bor. 19

still farther changeg had taken place in the work snd accomedations of the grevootional sohool by the the itr. Bacon geve his perlodicel nocount of Its progree in the Fonrth Report of the Boerd of Eduotion, covering the yenr from July 1 , 1924, to June 30, 1915. Saveral polnte of his cocount ere noteworthy. The echool had been moved once wore to atill other and larger quarter: in the ol a vale wigh sohool Bullalng, on First streot, neex Cheotnut. The first end decond noore of this building had beon rearranged to weet the new requiremente. The echool

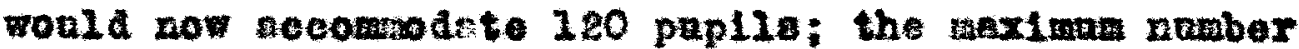
wes onrolled, and there was walting 11 at.

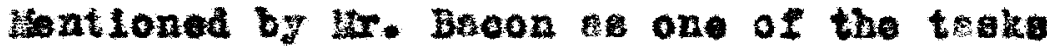
nadertaken by the sohool wes the placing of chlldren, 88 woon as theg waro prepared to go to work, In extleretory postione. With the inoreasing enrollaent this project we becoming wore difficult, but ith the holp of the Ben Frnnklin CIub, the Consumers" League and the Gaployere Ageociation way of the chilaron 
had been provided for. 80

By the tise of ghe rifth Bevort of the Board of Bungation zas Lovell had been medo principal of the prevocatlongl school. Enrolimat was op to one bendred and forty. With tnereeded fallitios for handling atudente giving promise of atill greater growth.

After-Behool sctivitles, for the first time, are antioned in thia report. The echool any of fire hours was so rall that organized play had to com in the afternoon. I chool chorue and folk-danolng olabs for girla were bolng formed. claenes in plano and violin instruction were belng organted and teans for eporte zore in proepeot. 21

Anong these student retivities, one of the noet noteworthy was the student connc11. The oomall was organised by the ohool and conolstod of o chelrman. ceoretery. an representative from el gropp or pupize. Thie bod wot weokly with the principal, and

20. Whe vour th loport of tho Bogrd or garaction. Fron July 1, 1914, to Jors 30,1915 PPrinted by the c. 2. Dearlat Co., Loulavilio, zent nokg), pp. 91, 94. 4. Beoon 1eft Iovisvilio Is ter to onter tho sutoxobile

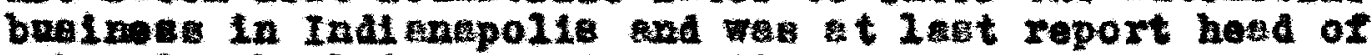
boye" ahool in erat comesticut.

21. The E1fth Renort of the soerd of guncetion.

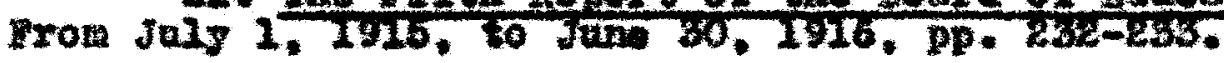


to this moting were brought problems and eaggeetlons.28 The peany lunch we ostablished in the prevoost1ant 1 school aurlag the school yonr of 1916-17. The Diroctor of gerny Lanohe errenged to have food prepared in a central attohon and transportod in therwos conteiner, thereby earins the oxpense of kitchen ognipwht. The cafeterie plan of menegenent was oerried ons by the girlo in oherge and the Innohroon proved a "gocial aget." 28

In this obse year a lerge nuber of puplie were enrolled in what wo called the "roentlonel gropp." hll of these paplis had completed the elghth Brade and wanted defint to trade propsrotory courses. Wont or thon bed deffnite choloe of shop oonze and looked Forrard to early omployment in the trede olected. The work of thi group attrncted the attention of employers. but, accoraing to latse Lovell, wo latent were those roung people apon the work plamed that not infrequentiy one bard the reply. "I went to com late work here."24 The joer 2916-17 wa the laet auring which the nawe "prevocational school" Fine used. The quality of

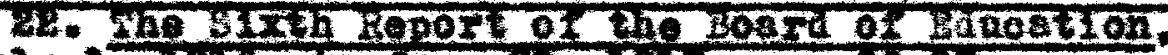
Prom July 1, 1916, to Jü 30, 1917, pp. 96-97.

23. Ibld. The worde quoted sre those of 148 zovell. 24. I01d., p. 96.
} 
-dabationer chlevament ettalned in the perlod from

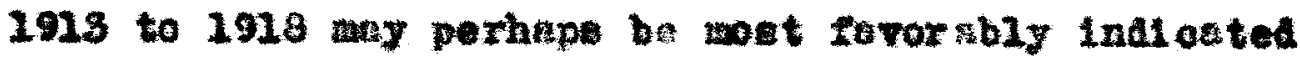
by this quotation from on of utes toreli's snat reports:

One of the gratifying derelopreats not od wee the inoroaced numbor of puptla tho found wore edreztion worth whll and so entered high sehool.

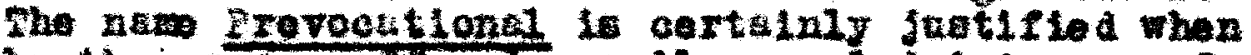
by the oowrso oftered, pepila ere led into one of two logleal ohwels--high sohool and denirable - uployment. One boy, who hed earned three dollers 5 day ausing vecstou, returne to sohool otating thet he needed eore odnot tion.25

IV. THe vockextes schoos

In 1928 the Fedoral snith-Fughes Let whe pasaed. The purpose of this cet whe to promote wrode and Industriel gunotion of lese then oolloge grede. It provided an propriation for ealorlo of toschers of trater. hom economies, and lndustriel suljeota in the

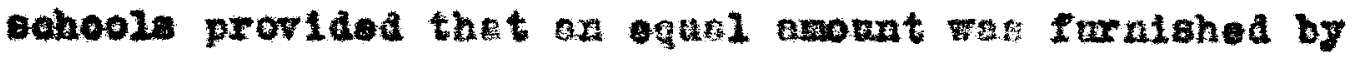
the $200 \mathrm{al}$ sehool funda. To guelify nadar this set the gchool aty of tho prevocationsl sohool wis lonethened to alx and be he houra, and the ne of the gchool whe chened to the sonitevill. Voontionnl sohool.

This chenge whe scoospanted by qulotened growth

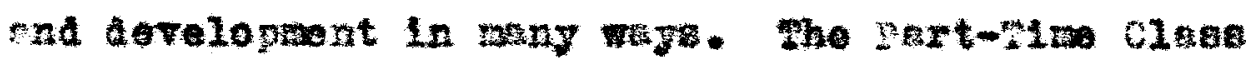




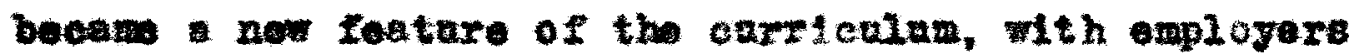
sowstive sending their "Jnnior help" to attend school for two howe delly $(8: 30-10: 30)$ without 10 es of pay. 26 Tow equiprent was aoquired sad new cour aes continue117 belng openod to atudenta.

Fo moet a populex domand the Comrerciel course was opened in 1918. The growth of this dopartmont was tendy. Shorthand, 5yporriting, Bookiteplng, Compto-

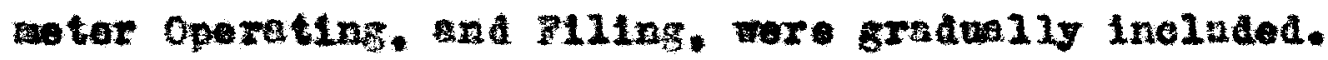
Th18 work, Wh the related aeademio jocte, including

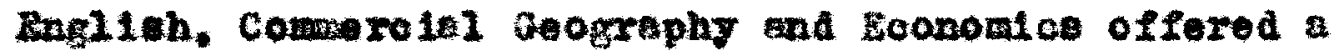
well bal noed course for the trelning of efficlent offloe neglatanta.

The rapid growth of the electrical industry. affording attractive and profitoble omploytsent to poung workere. Ied to introdnotion of that departmont of study at the Vootional cohool. The edncationel oontent of the trade is snoh $s e$ to provtde broso ingtruction 11010. and the eleotrienI department of the eohool wes deslgned to Iumigh nenrly poelble preotleal working eonditions encountered in the trade. The work ofrered geve studente the opportentty to wase

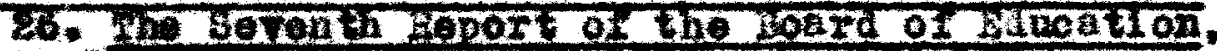
Frow July 1, IsN, to Jane 30, 1918, pp. 130-131.
} 


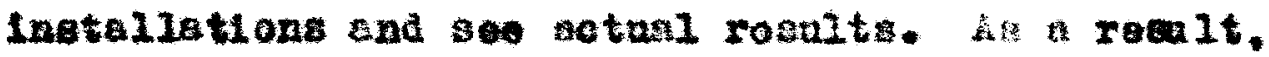
ctudont a comleting this conreo have beon readily absorbod by the indnetry.

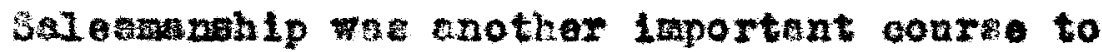
be derelopel. Herchat becoming moro and more careful In the selection of rorkers, thero exis ted a ned for instruetion in asloenanehip. Inotrcotion wta givon in the following bronches: atore orgenisation. storo aysten, merohendice, typos of castomere ond store Bervice. Iroctice in selilng required of atucents. This wan secured in two ways-in the snles roon of the oohool and in the department otore of the ofty.

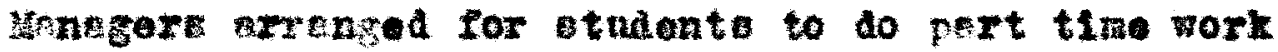
and epecial pales pork.

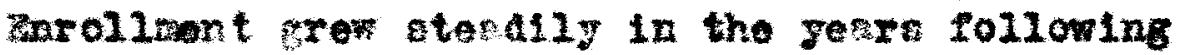
1910. and the galdace tontro of the work dono at the Voostionsi school grew in proportion:

Leny youns people have rieited the school to lenrn the it ofrered end the $t$ recomandetion would be dode for the lation of their problema. Ianlte heve conferred Ith the prinolpnl Iraquentig when

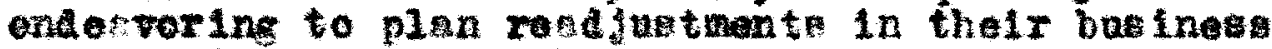
or induetrinl 11fe. The puldsuo of etudents into a cholce of work for mich they show the grentest inelinstion or sptitude ofton pointe turning point in oharaoter developmont veli in preot1-

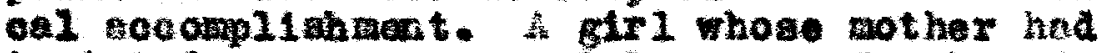

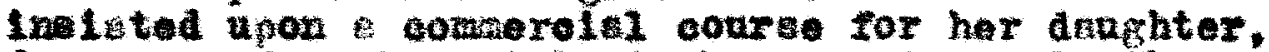
found now Joy when te last whe was pleod in the crosensine dopartwent where her holo ettitude towards study we changed and remarisable progrose 
noted. ${ }^{2}$ boy whose parente were galte determined thot he ahould become akilied mechente 18 not poraning his high echool ookre of th industrial

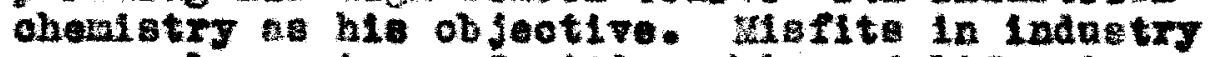
mon lower trpe of cltienshlp and 11fo minus satiafaction.27

The work of the alght school is antioned for the firet tine in the prinolpl's report to the Boerd or sduation for the echool yerr of 1921-ise. In thet jear the night sohoel wa sn anrolizent of three hundred end alzety-rive etedente. Courseg were ofterod in Buglish, arithwetio, penmenship. bookteaping. Btonogrephy. typewriting. allifuery, aroeswing, 3nglish for Iorel gner:. and Anerleandution for those tho had applied for oftisenentp papero. For number of these clasues there we wating 118 . 28

The waltiag list referred to ladionteo thet the Iscilltias of the school were being etrined to theet

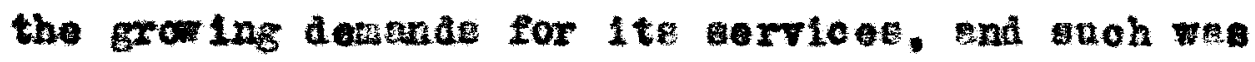
Indeed the che. shere were many regueste for new corrseb to be offered. The lnduetrial growth of the olty and the inoredsing nubber of opportanit1es for trained jouth were reoponstble for thi trete ox arfairs. The jear $1922-23$ browght on increted number

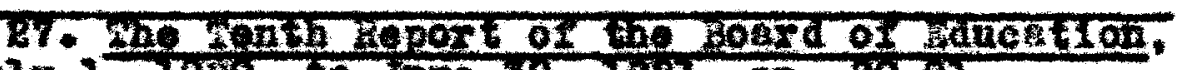
Tron July 1. I920, to stane 30 , IVeI, Pp* 90-91.

20. Tho herenth joport of the Board of Banoa-

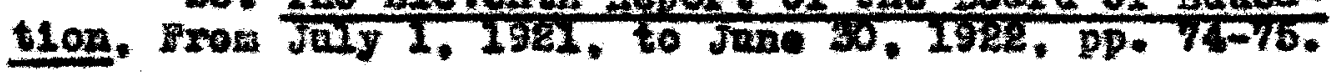


of calia from eaplogere for gredaster of this achool. In oom depsrtants the reque ets for gradnater expoeded the number aviliable. 89

During the eahool year of 1924-26 the Vocationel Sohool rouched a high pot in ite schierenont. The everage da11y attendance at the echool in thio year was 303.50 Early in 2025 seoting of the Altruea clab was held at the Voontional sohool. and the faote difolosed in oonneation with this beting indiogte the sort of inetitution the echool hed become and the beritage whioh Theodore Anrens Frade Sohool was ohortls to reosive frow it.

Thie session of the Altrase club was held in January, 1925. Forty buetnese ond profoestonel wonon. representing es ans indretrioe in Lonievilie, spent ene orening at the ohool. vialting the night elasges and booming generaliy reguatnted with the vnried Bctivities. Sach intormation regarding the fwotion of the sohool we galned frow this investiggtion and from comente be by Irovell in har speech to the

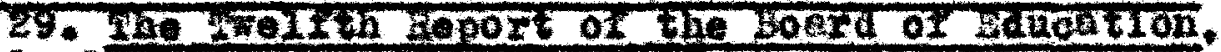
Tron Jaly 1, 192\%, to Jü 30, 1923, p. b6.

30. The Thirteenth zoport of the Bosrd of Ednoa-

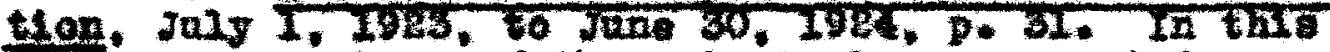
atrio report ealary of the prinolpel wae reported as

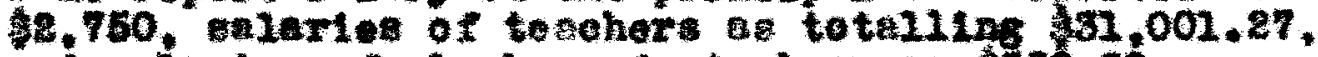
and ealarles ot clorke and tockun as $\$ 600.00$.
} 


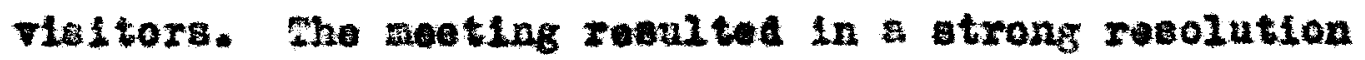
whaly oomanding the work of the cohool. and argently reoomending that other alab gropp in the olty. partioulariy those which were represented in Lonistilie industriee, ahonia Iikemise piait it in the interest of wider knowlodge of the sohool. 31

218 Lovell's speooh on this ocection to the Alruge club is noterorthy for ite oomoct sumary of the origtn, alas, and achleresente of the Voontional Sohool. She explatned that the work then beting aone In the school origlnated 71 th a group of 10001 women connected wth the consuare' League soon after the Inangurel of the polloy of taking achools out of polit1es. Thos wown, sho oald, coneldered the quetion,

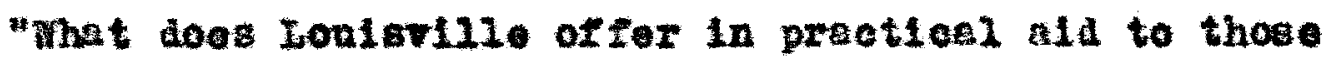
who suat oarig enter into the ocompetional ilfe of the olty?" end the firet etep in the extalionsent of

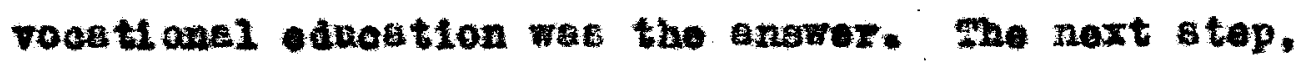
whot trades to of for, was taken after an export invest1getion of industrial condtions here 20 to a gurey which wa ade of those intugtrios in which trained help was wot oroly needed.

utas Lovell and furthor the the rexponse to 
the course of work given in the cohool had excoeded

the capecity for treining:

- The bullaing is open norning, efternoon and night to tudents seoking to beoon tralnod and ofriolent in the crafte and trades th interaet thom. The younger boyo and girls attend the regular dalig achool boestone in the mornine and early orternoon, eome teking part-tine opnraes. The arternoon olabes, 3 to 5 o'clock. are wostly part time, and the evening classes are exclubively for employed roung wen end Fomen. 1213 otudente wero arolled in the varions clabees last yenx curinz the two terwe, and alreacy 860 namge are on the enrollment boolts for thit term. 38

The orafte and tredes wentioned by $x^{2}$ iee lovell wero brought to pabile notiee by tho oxcelionoe of th wioh they were taught at the Vootional sohool. In book-binding for inetrmoe.

For the fourth consecutive year, the theodore Ahrens Frede Sohool, enceebsor to the Ioulavilie Vooetlonel school, hes been honored by being evarded firet prise in a notionel bookbinding conteet conducted by the Employing Bookblnaters

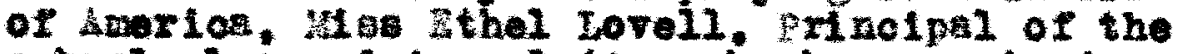
Bohool. learnod in lotter the hat recolvad Fros F. Palner, oheirman of the orgentzation's Educetional and yoontional coraltee.33

sine 1986 wae the IIrst yenr in which the Institution wes knom by the name ned fbove. the threo provious ewrard met havo come daring the time the term Vooatlonal sohool mas in nee.

32. Ibro.

38. The Ioulevillo gimes, Detober $28,1926$. 
The lapertanoe of eneh an arord 18 botter underetood when it is obeerved that roestional bchoole from all over the country were ontered in the conteat. samplea or bookbinalng work hard ng beon gent fron the varlous echoole to Chioge where the Hational sasoolation of Bmploying Bookbinders wa in convention. In edacetionel comalteo, composed not of teschers bat real crartamen, was eelected to judge the entaples of bookbinding on exhiblt. The contest, held annually. ves Inntituted in order to atinulate greater intarest In the binding creft in aberton, be bookblnding an art hae been gradulily dying out in the fultod stater. and weh of the work doring roeent joare has hed to be eent abroad. 34

In the departzent of ert. L Louter1110 nowapeper had this to say regirang an ert exhibit of the vocathonal School hold 1ate in 1924:

The art exhibit which the design departiont of the Foostional Sohool hes been holatn the lats fer days. has nttrated a breat denl of Interest end adrirtion anong thoe who have seen 1 t. Svery Iine of art arok is represented in the display. Sosrfo of nnuavi desim and pertection or finish, bowle, boxes, calondars, qualnt novel tien, leather book ends. wany of whioh cannot be fonnd in loesi storea. And host of other ertieles of renl besnty are bans the things on oxhibit.

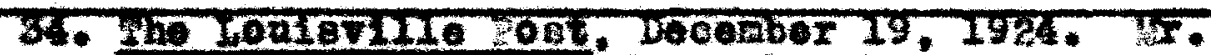
cherles $P$. Letare he oharge of the bookbinaing departmont of the sohool at the tife of the ae araras. 
The cohool has taken nono of the rort ontelde to bo Inl ahed. The electric, foodmork, bindery depertrents, eto., all abef ot in Inishing the articles whon thoir help is needed.

Wot only craft work but oowerciol designing ie on exhlbit. The aresereking deetging was of epeciel intereet.35

It was on institution of thle sort mhioh at trected the ettention of it. Theodore Ahrens. Ils glet to the ochool. intended for 1te expaneion and development, we annoapcod late in 2984. In the epring of 1926. while plans for this expencton were in the meking. he Vitied ell the ohops and classrooms of the Vocktional sohool and on loaring, comanted, "I tind you are doing fust what I an talking about." It was a thrilling aly for the tecohere and papila, parente and patrons who hed so earnestly ondeavored to make the not of the opportnaltiec presented when the Eoard of Macstion amouncod thet ir. Ahrone had giren two bundred and flety thousend doljars for new trade ochool. 36 Thie gift and the announcenent of the plans for the Theodore Ahrene 5 rate school did not wern that an

35. 1610.: Decenber 20, 1924.

36. Ioulgrille civie oplaion, october $17,1926$.

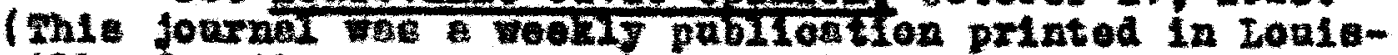
v111e Lor the aine yeart between 1921 and 1980 , and ILnelly ous pended beobuse of is of of advertielns support.

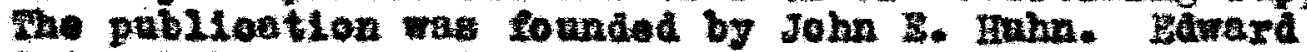

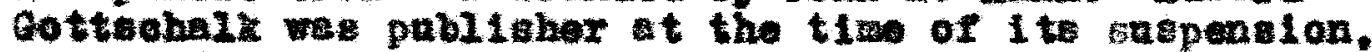
wh Alfred J. Strause oditor. It wae not published for protit and had its alm the betterment and progress of Loulavilie.) 
ond ha ben pat to the caranr of the Loniovilio Voestionsl sohool. On the contrary. It moent that. nnder 1 ts new nawe, the cahool wonld oarry on with now avenne of opportunl ty opening betore it as a roenlt of 3r. Ahrons' Benorosity. Those who had been inatruental in entabilshing the firet rootional training in Loulavilie wero far fros anrends to recogaizo this fuot. comonted the Loulerillo c1vio golnian: "Coming at this tim the gift will bo most gratifying to the retiring president of the Board of Iducation. Who, W1 th ara. Harry Bighop. wa Exeatly instrumental in the establishnont of the Voostionel sohool. 87

The Conennore" Iongue, parent of the Voentional Sohool, In Ite annual meoting hela at the sohool in Apr11. 1925. componded the generosity and vision of tr. Ahrene. In adition, the ohenge in the institution's nate to honor its hew benefector was ondorsed st thlo

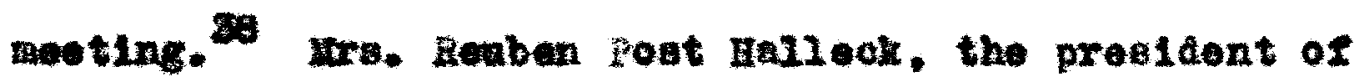
the Consuere" Leagne had even previodsiy expreseed the

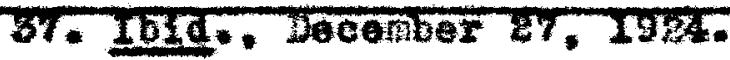

30. The counler-Journal, Apri1 15, 1925 ...

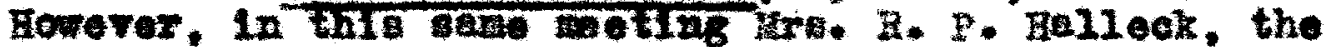
re-aleoted prosident of the loagne, engreated the rotalning of the word "Vocational" in the now name. Stre. Fallees atsed thet the cohool be called "the wheod ore Ahrens Toeftional and Frade sohool." A recomendetion to that exfoet was later prebented to the Board of SenoatLan. 
thanks of bor organization for what ${ }^{3}$. Ahrens had done. 39

It was not only the sdult oftigens of loulevilie Who looked fartera with pleasurale anticipation to the Inoreased ednotional opportunities to bo afforded by the opening of the Ahrene rrade Sohool. Fhere were those even more alreotly conoernod, boye and pirls of Migh echool age, eapectelly those in reaty enrolled in the Voestional sohool, who wero begluming to be affeoted by the proepeot of the larger bn11A1ng and ogalpwent. In Jenwary, 1985, group of those, girlo then enrolled in the Vocatlonal Sohool, Bavo a "book" party for the purpose of eterting 11brary for the new ballding to be conetracted. sore than a hundred booke were contributed. 40

Ane so the roostional sehool oam to an and, not of Ite history. but of the second porlod or lta developnont. Beglaning ae the Provoostional Sohool in 2913

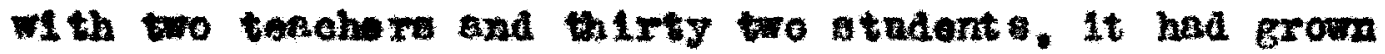
to tho stage whore. In 1925. It had a tnonity of nineteen and a tndent body, Inolud nre all departmonts, of

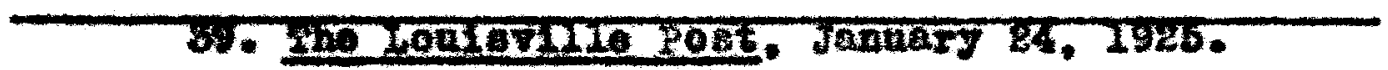
10. Did.. Jannary 23. 2926.
} 
one thoussnd, two hundred and oleven. 41 In the Theodore Ahrene Irede School, and th thes Lovell continulng os principal. the opirit and cohioremonts of the rocational school were to bo precerved and intensirtod. 


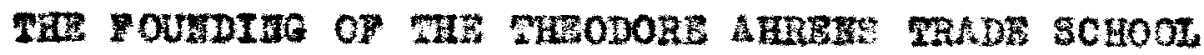

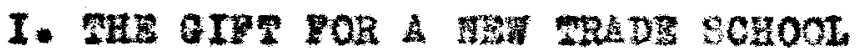

"Moodore Ahrens, Leuleville capltallet, prealdat of the standard sanltary zanurecturing cospany, has present ed Loulerille with christwe zift of \$150,000 to be weed to establish a trede sohool in the eity." 1 Thece signirlenat worde, op parlng in the LouleFile yost of Decomber 24, 1924, wate know to eftis ene or Loularille the act of clviomindedness and generosity which we to make posible the creation of the theodere Ahrons Frade School. The gift, tho largest ever presented to the Lonke Lille sohools, had been announced the previous nisht in reeolutions adopted by the Boera of panestion. These resolutione rend as follows:

Reav17ed. Fhat the Soard of Zduction, on ito own behalf and on behalf of the citinens of LoulsVille. Beoepte with profound thante and a deep aenes of gratitude, the aplend 1d glft of $\$ 150,000$ for a trade echool, to to this board by 1 is. Theodore Ahrene, en oute truding, brosd-minded, generous member of this comeani ty.

The board, while thaful of the great rine and worth of the property thus generousiy bastowed. eppreolates no lees the 11 bersi puble opirit 
which prompted the gront gift, and wieh wakes poent ble the etucational developmeat, along Industrial ilnes, of numberlese pereone who stand in need of the helpfal trainting woh this sohool *111 onpply.

The boerd oannot too atrongly expreae 1 ts alnoere eppreclation of $2 \mathrm{r}$. "Ahrens" groet generosity and Lindnose, and aganres him thet this sohool. lounded by hin, will erer stund as a lastas monnmont to hit good naw and o ble anting to the Induetrial I1fe of the eity.

Resolved, Iarthor, That the cohool, when eateblishad, be newed and know the theodore shrons Frade sohool." 2

4x. Ahrens" gift whe de as the reanlt of a

letter vritten to hit by $\mathrm{Dr}$. Aibert B. Moaver, member of the Board of Fancetion.

"I got \$150,000 for writiug one letter." Dr. weaver eald, "not for ayself, but for this end the ooming genoratione. And we are golng to bulld a bonkEant to Theodore Ahrens, not of cold marble in Cave Hill por of any broes atatio on eny of our ctroets or in our parke; bat renl 1fre trade school that w11l turn out wohento for the different tradee and make oftizens of our young an who woeld otherwiec be loafers."

Back In 1924 man tho ldon of a trado school IIrst wes brought to the attention of sr. Ahrons, the oost of sach an indtitution atrak the bathtab agnate

$$
\begin{aligned}
& \text { 2. Ibra. } \\
& \text { 3. Ibic. }
\end{aligned}
$$


as grohibitive, acoording to correspondenoe in the handa of Dr. Eearer.

"I relt thet Ir. Ahrone would be intereated in anch a projoot and I wrote to him about it." Dr. aeaver sald. "I also brought the ther to the atten-

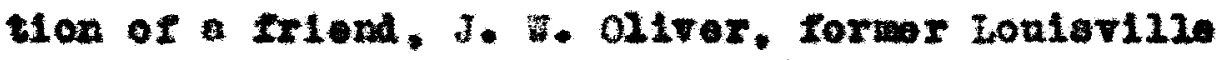
newapeperwan and then $\mathbf{1 0 0}$ proeidant of the stendard sanitary 政anafrotaring Compny.

Dr. Weaver polnted out to ir. Ahrene that many boye and girle leave Bchool after the alxth and aeventh Bradee, wholly anfltted to osm living, and explained that the of ty had no fand for the construotion of a trade sohool.

"Cave use to alther the liring or the dead," the dentlet wrote to 数. Ahrons.

"Som day you fill come to the Penrly jates and salnt poter will okk: "That " gour namo?"

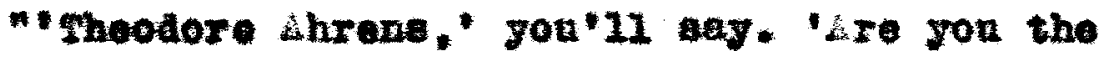
Wheodore Anrons who gave the sohool to Lonleville?"

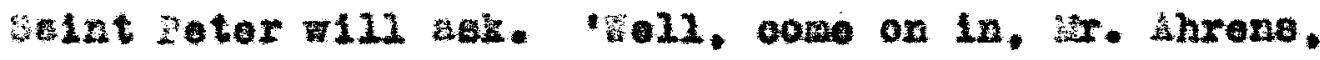
yon"re bloeking trafilo out there."

A fow dage later a reply wBg recolvod from 
3r. Ahrens, who then in P1ttebargh as preal dent of Stander senitary:

Pltiburgh. 5ov. 5, 1924

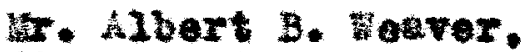

The preeldent.

Board of Edweation,

Lonisvil10, 5y.

14 dear doctor:

Our watual Irlend, 3r. J. Bhown your letter of Wovenber 2nd. You engeest thet I provide the funde to bulid oultable zrade Sohool bullding in the city of Ioaleville. You waow of course that I an grastly interested in the oub jeot, not only to provide proper training for plembers" apprentioes but for all the other bullaIng trados as woll. To bnild and oquf ouoh a ochool, however. La blgser projeot than I am able to andertake. I have no $100 a$ es to jugt what would be roguired but legine it wonld coet anywhere around $\$ 180,000,00$ or $\$ 200,000,00$. Thet is * nore abltioxs project than I bblo to consider, although your letter rosds ghty well and ratos regret that 1 an anablo to do so.

I wonla Iite to tali this water over with you again oow tive then I in LoulBville.

Perhspe to colla betweon ne work out wa plan by thieh gour ldea coula be earried ont. Leeuring you of cont inded interest in the mattex, I an

Very traly gours. Theo. Ahrene

On Its Face, the letter appesred to be pollte rerusal, bot Dr. veaver was heartened by a paragraph in which the suatecturor oxpreased his with to discuse the ten further. And then, couplo of wooks later. 


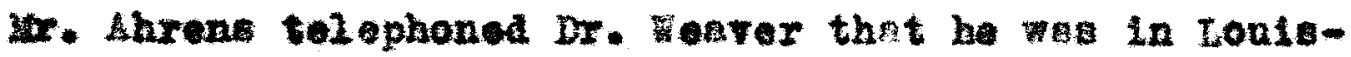
rixe ond wanted Dr. Feaver to lunch wh his, the latter accepted the invitation earorig. The regt in hiatory, the history of the Ahrens prade school. The eanner in wioh the Lonistilie Bonre of Saction responded to ir. Ahrons philanthropg heg alroady been noted. The elty newepepers, ar well. reneoted the prale glven him by the general public. Sald the Loaleville derald:

The parpose of itr. Ahrana wae to fill a gap in onr nohem of oducation, to maice good la ex not arily to be wet by the oxisting boxees or achool revente, and it was what he fornd in other great elties and whet he learned of it utilsty and value which prompted him to become ldent 1 lied with a trade sohool for Lotisville.

ty. Alrren is extinentiy of those tho make this vorid of ours, this everydey, thus humdram world, a wholesom pigee in whloh to live. Ho belleves in the stare.5

It was clear, 0.180, to the Loulerilie mimes. that the ingtitution Viand ized by or grost advantege, not only to the lnaividul gtudent. but also to inatustal Lontarille:

Theodore Ahrene' gift or $\$ 150,000$ toward eatablishng trades ohool here 1 a forcerul

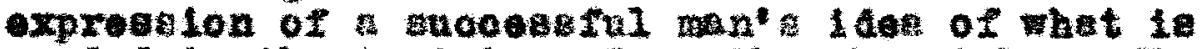
needed in the training of youthe tho wioh to fit the elateres for pork in the induetrial world... The Ahrowa Behool is intended to be truly 
preparatory. Ite eraduates showl be able to gualif linedintely for place on the payrolla of Loviev111.'s factorles.

Opportanity is the ohler orfering of Amerioa to lte citisenship. The Ahrone sobool w111 give opportanity to the killtal and the ambitions. It ill remove the neceacity for apprentlceship through years of poor pay and costiy naletakes...

The sohool should be inoreasingly naeral, for as loulstilie grom, tho domend for trained

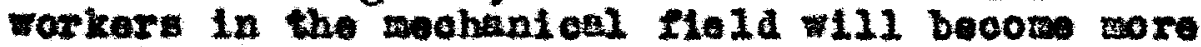
preselng. The plaolng of grest industrial unt here will inerease as Loulevilie'a advantagen

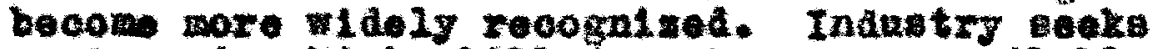
eentere in wich okilied workers are avtiablo. The foet that Loalavilie is chooling large numbere of experte $\mathbf{1 1 1}$ be an attraction for investore here."

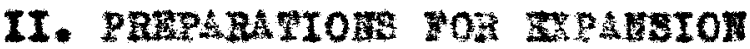

Fariy in 1925 the Bonrd of Banoation got dorn to work. planning and investigatiog, 2aying tho groundwork of the theodor thron Frade Echool. The sehool. had been coneelved and plamed th the parpose of ritting inte the Induetrial noed of Joaleville. The firet step take by the representatives of the Bosra of Streetion wa atudy of the indutrial gtuetion of the ofty. made with the holp of a conksttee of the Board of Frade. In wapplag out the conrsev offered and In obtaining the best oquipment. the oooperation of mufecturers, ba11dere, trsdes mione and othere 
wao wight. \& thorough burvey was nde in order thet the Gohool. When completed, would be able to weet inoreasing arployrent denands es foreost by the growth or population. The following gotation lilustrotes

the ans and acoomplishments of this aurvey:

Induatrial eaploymant statietion have bean tarned over to the Board of Bdncetion by the Board or Frede and Abeolates Indnotries of Kentucky for in Iormating plans for the trade sehool to be ballt by the . . Thand avallablo by Theodore Ahrons, president of the stendard Sani tary tanufacturing Company.

The report ade to the Bosrd of Edneation repreaents the restit of a questlonnire aent and plente en to namber of ek1110d omployes. numes of trades representec. number exployod at eAch. sproxinate number of tralned spprentices win tron two to four years trede cchool freining.

Seventy-fonr indug tries are repreatentod in this ourveg oumary. Inoludi ng oatnbl in wonte as Follows: Ifteen printing. throe 11 thogrephiag. two engraving. twenty fumiture and Allied liaes, six sohinery manfacturing. two gtove fonnarles, Tose ston and tile plants, alx olothing and textlie plants, one harnees coneern and nine alsoezlaneons plants."

A jolnt oomaltee of the Louleville bourd of Frade and the Loufsille alvislon of the Associated

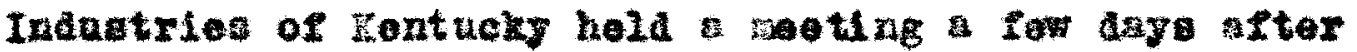
the tiwe of the soore mentionad report. At this reting 1t was resolvod that cournos in brioklaying end plestering be inoluded in the currionin of the 
trade school. The combitte oorierred w1th 1 . Byron 霍. Hartloy, auperintenient of sohoole, and tar. R. R. Denghorty, anporinterdent of manul training in the elty sahoole.

The joint comal ttee turned over to superintendent Lartlog information obtalned in a arey or appren-

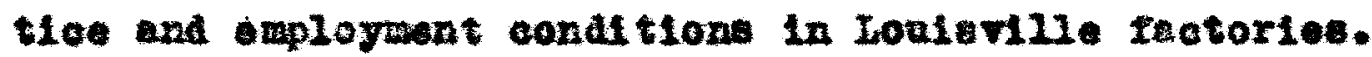
This oovered many typos of enployment in 200 Indastrial concerns. Whe ooual ted roted to cont inne as permanent organisation for the purpoed of cooperating in the sucessefal oonduot of the bchool and aldis in the adsorption of atudant by industries aftor eraduation.

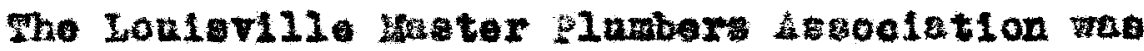
anothar organisation which prowised hasty gupport to the Rorrd of zawertion in equipping and intoining the sobool. This group, Ilwe Aasociated Industries, alopted renolutions thanking and prot aling fr. Ahrons for his generous gift to establikh of trade sohoo 8 tr. Ahrons himself, not satiorled rerely with provlalng the neoeseary weane for the Lngtitutlon, gave libercily of his time and orfort anring the perlod of cereral plenalng* serly in January of 1925 he, in 
coupang with Ir. Hartlog. the sohool superintendent.

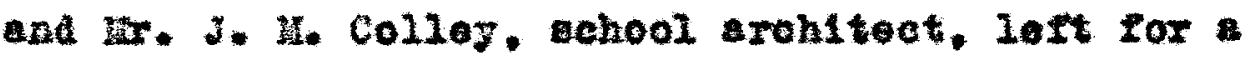
trip to anditer of ofties in the sorth sna reet to - thidy trude cohoolo and other phasee of ednoationsl work. Whe trip. 160 ting between 8 week and ton days. inoludad vies to to the trede cohoole of silwarkes.

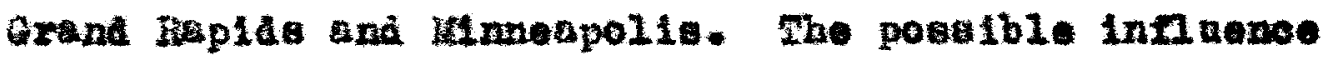

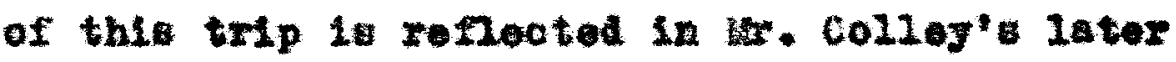
deciston to plax the bes fostures of trade aohools in Clnolanti, Indianapolio. St. Lonis, end Grana meplas. and to combire thesi in Lonievilie" projeot."

\section{ADDTIOBAI GIYrs}

Frobably as reant of inveatigetion undertaken

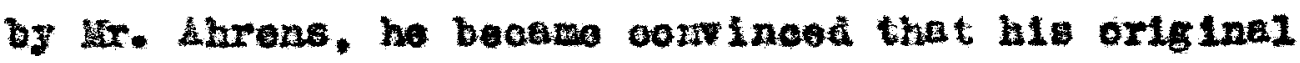
donation was not fufflotont to give Loulevi2lo the find of sohool that he had In vind. As any rete, on Apri1 10. 1925. annowne enent was bedo by Dr. Teever, president of the Bonat of zduention, that thr. Ahreng hed edded M102,000 to his original gift of $\$ 250,000.10$ in a

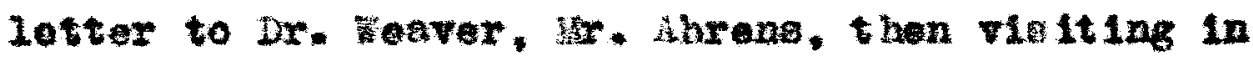
Calffornia. ald that he hed lnapected several of the

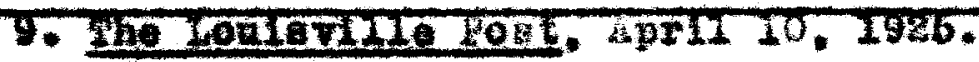
10. Ib2d. 
huge trado bohools in callfornila and felt that tho original amount was not enough to fire Loulsvilie the school the needed. At the time ir. tyrick colley. school axchitect, was elresay Forking on his plens for the echool, and changes wero necesattatod by the sdalt1onel glft. Dr. Feaver seld that the 100,000 was

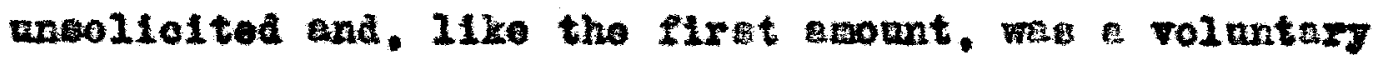
contribution on IR. Ehrens" part for the benefit of Loulsrille' future employees and the Industrieg themnel ves.

It taight well have been supposed that 1260,000 wonld be the $11 \mathrm{mit}$ or $2 \mathrm{~s}$. khrons" generosity to the new trade school. However, the ond hed not come, even

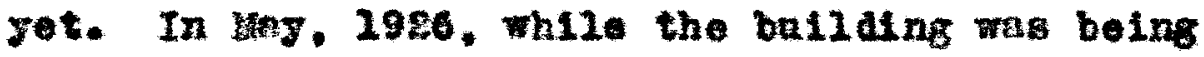
constrncted on plrat streot botween walnat and chostnut. the Pinnno Comittee of the Soard of EAncation made knom otill enothor gift, this tise of 650,000 , with which to Inetall gomed in the Theodore Ahrens Prade sohool.11

tr. Byron uartiey, Buperintendent of schools, Beid that in molint the aondion for the gonasinm itr. Ahrene felt the school would not be comple te unleas the etudents receifed a physleal ap well se technical 
trainlng. I2 He expreesed regret, cocording to ar. Hartleg. that the elty of loulaville we not able rinanelaliy to onxry out buo progran in all or the ochools in the ofty. o he regarded phytioal tralulug funt $\mathrm{a}$ essential a mental and teohnion oduontion. 5hit expresston of concern for the phystend well-belng of ehool chlldxen wae characterietic or

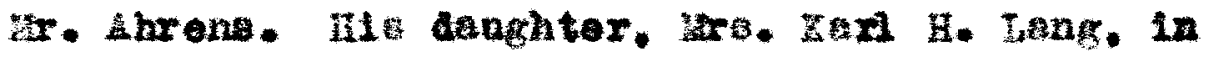
cowenting upon her father'e views, sald thet he "never coneldered en ednodition complete anlese the bodg was also perfect. He epent his youth on the grw noor of the old Gerwan purngemelnde. In those days more than now Furnere tumishod its mentol tralning and gtimletion. Betureliy, he would not conelder school cosuplete unleas it had a far. de really wa horrified when he resilged thers Fas not a gra in the cobool."13

The adaltional 350,000 for the grmasina made total or $\$ 300,000$ given for the orection and equipront or the trece school whioh we to beer ist. Ahrens" nabe. belng by trex the largeet donation ever node by one indiviand for the betterment of ednotion in

I2. Iura:

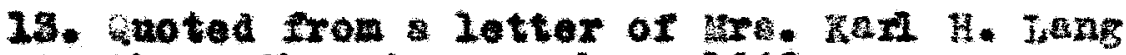
written to the athor in yovomer. 2940. 
Loulevilis. 14 the soboel wes, at the tist of this third fift, plenned to be ready for the reception of ctudente at the beginning of the tern in september (1926). and the rork on the bymatum, wade posetble by the latect generow girt of the founder, was to begin as eoon as the board conld let a contract. The grwantam thus rade posible was to be oquipped for vee as an and tor Inn, and the bneemont of the new unit was to hoves the sohool lunchroom. ${ }^{15}$ In accopting and aoknowlodging the gift, the Board of bucation adopted rosolations se rollows:

The Board of sabeation agela has ocossion to axpreas to sheodore Ahreno its elnoere thanke and gratitude for the deep interest he has anifected In the publis cohoole of the elty and the splend id generosity which hes cocompenied that interest.

"ive offe of 50,000 which he has just made. 2ad whloh the board has gratelully ccepted for a neoded cyunasing the trade sohool which beere his neme, and hich was oatabliehod by his manirlcent donetion of 250,000 , wakes it posrible to eive to the studente of that ingtitution proper physion developrant and dirersion along ith thelr other preotloul tralning.

"The gift is the aore signifiont and the wore epprecle fed and palued stnoe it will enable the board to round out and complete in proper form tho ra11 work of thobe who bay enter the trade bohool.

14. $10 t$ even exceptras thet of 4 . Coleman dayont who wate poselble the duFont sonal Freining High sohool-Fhe Louirille Zost. December 24, 1924.

16. Civie Oplalon, June 12, 1926. 
The board therefore. tor 1 teell and on behule of the oftizens of Loulevilie, and rore partlenlerly on behelf of the present snd futare youtha ond chilaren of the city who are to be the diroet beneflelaries of this wost generong gift, extends

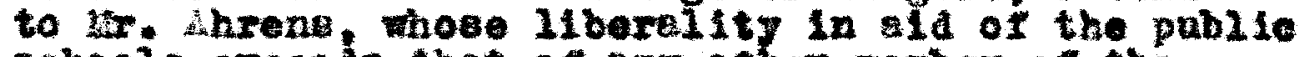
choola oxceeds that of any othor wowber of the corranity. Ito warmed thanks and spprecintion."n16

The Lonistile prose expreased blatlar comenta:

The ceoond adationnl $\$ 60,000$ presented by

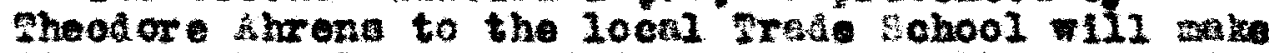
it o cosplotoly rounded inatitution. Fhis gift is

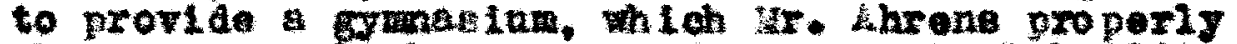
obeerres chovil be part of every sehool bullaing In the elty. The wne edrenoed by is. Ahrene for this sohool no totale $\$ 300,000$, which amoant to ten oente $(1.20)$ on the tax rate. If pald for out of current lev1es. Hithont thing into cons 1deretion the sehool's inealculable value to the comand ty as the yeare roll by. this if way of vienolining the direct linknolis bonert to every texpeyer reanting from this benefnetion. It cmounts to a eubstantiel diccount on every tax b121.

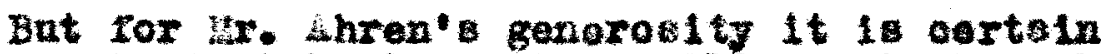
that zrade school for Loulevilie would hate been beny yoaro delayed. It 15 therefore not only an inetrament for Individual eduoetion. but a faetor In hastening the comanity'g progreas. The growth of areot oity 1E. after all. minig dependent on the publis oplrit of Fer, and lt rould be diffionlt to nase $a$ wag in wheh this bplrit can be more Iinely retlooted than in advaneing the casse or education. ist. Ahrens" example should serve tas an inepiration to the ofrle pride of othar outtanding oitisone. 17

$$
\text { And co. through the Itbermilty of one of its }
$$

citis onv. an exeeedingly userul ingtitution of lo:rning wa to be developed for the ofty of Loninvilie, a ahool

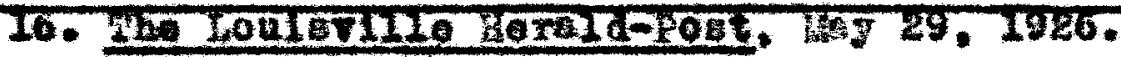
17. Ibla.. Janary 1, 1926 . 
dorotod pribrily to tho tonahing of tho tredes and one of the compartive xow of its xiad in the dat tea stetes. Batobliahod on Firat Stroot botroen find and chostrut, it wat looted on site slrady riah in trations in Iousavillo'g sohool 1120 . As previouely noted, there had been alroady bator it

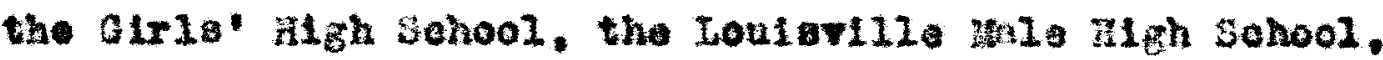
and sore reoently the Ioufevillo Vocetional Seitool. A better opot in polnts of locotion and hatorloal Interest covid hardig have been fourd.

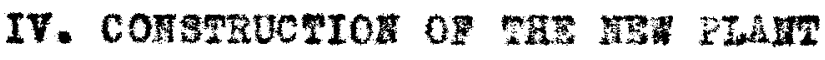

Contricti for construction of the plent to house the theodore throns Frede sohool wero ewerded by the Board of Nducation at of the night of oetober 6. 1926. Shese contracts totnlod 1245.410 .16 Ther did not. of ookree. Inal ade the amount for the Grmalum, bixce it has been coen that dy. Ahrene' Ift to provide for armalum was a soparate one, coming at $e$ leter dete.19 whe anount was also oxclualve of approxdmtely 910,000 required for hodting end ventiletirig the balldine:

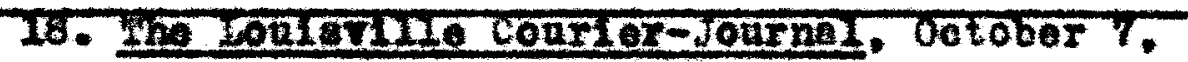
19. See p. 69 of this the eld. 
The contracte cal For completion of the new ballang by oetober 1 . 1926. but wewers of the boara gela lat night they expectad it to be resdy tor ggonpancy when bohool opent nex Soptember. 20

In order to provide ample grounds for the bullang. the Board of anowtion had prehaeed for ty reet additional rrontege adoining their property on Firet street. 21 mis nede s total frontage of 178 root. 22 Tro mellinge whioh hat oooupled the forty roet sadtional and tho front of the old Vooftiond Sohool wero to bo recked to clear the alte for the new trede ehool.

The bullatng of the Vocktional sohool thue being in the proceat or demollahrant wa fow znd $a$ heli storieg in holght ith a gane tront. It was one

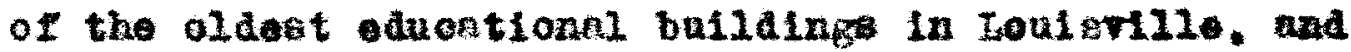

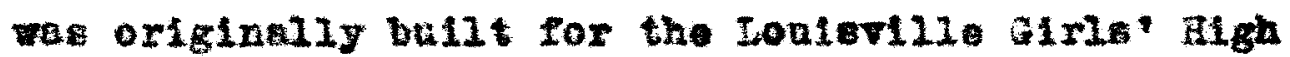

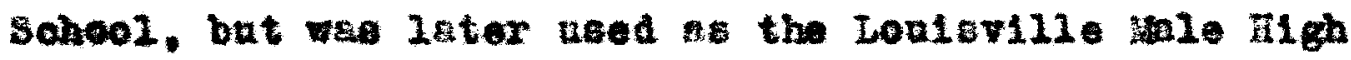
Sahoo2. 23

Fow of the rourteon rooma of the old bullalng wero to be tom arey to weke room for the new etructure 20. Whe Conrter-Jonrnsi. wotober 7. 19kb.

21. Ib1a. Detober 9. $192 b$.

22. Ifla. october 7. 1925 . 23. Sae p. 63 of thic thes 1 . 
with clabses continulfs in the rectining old quertere while the project wos under ray. The old portione were finally to be remodeled for clabroome. It was intended by the board to raxe the latter at a future date when there would be furficlent runde to construct adational vinga. 24

ate planned by colley. the wohool arehlteot. and tse Iorell. the plent was to be "U" shsped, baing bxilt around the portion of the ald Foestionel school juat antioned. The couth Ing extended book 90 foet trom the otree and the north aing extended back 200 feet to the alley. The nev ballaing wae of tire reastant congtration. Facod with glazed briok and trinmed wth Bedrord etone, and contained the aduinistration ofrices, wowe clave roow, and the bhop wings. 26 It coneleted of three 210ora: bround noor. Arot noor. and aocond thoor, the ground noor belng olightly under the s1dewalk Ievel. Fhere were three entrances oft Piret streot, one large wein entronce and two buller Hanking antravoes. the whole bullating wat or molern cowerola design. Indionting both the industriel type of work and the dueotionn activitios balng conancted therein.

24. Whe Caur az-Jourmal, 0etober 7, I9E6. 26. The Loustrille jerala. April 22, 1925. 
A oomprohend ve ploture of the Ahrens plant at the the of ite completion appears in the progrem of Its dedication oxerolans, Decenber 1, 1926. Jnder the heading "Pacte sbont the shoodore Ahrene Prade Sobool" appared an explanetion of features of the bullaing and 1to equipment. Fron thio explanation is drown moh of the Inforation in the followns paragraph. The now plant was destigned to accomade te 600 studente. Aquiprant alone cost nesriy \$200,000 with each shop and work room sully equippod with the very latest mohinery. Wodel tactory conditlone were oarried ont in the construation of the shops. The greatest awount of roov wo doroted to the shope, but clagaroowe were provided for related aodeste inetruction. 26

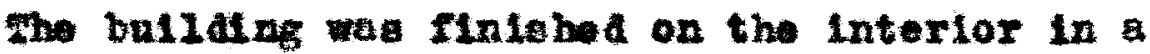
fally atllitarion wanex, watorials belng ased whioh are paily cleand and thorefore otrietiy onitary. All corridors, tollet room, etc., were lined with glesed brlor walnecot and had teraszo noors. The shop rooms were lined th glezed tilo carriad clos to the oolling. All wallo and collinge of the building. except

26. CIV10 OpInIon, Jwe 12, 1926, 3hope vero provlded tor the rolloming type of work: obinet. wehine, sheet tal, plubing, leatriobl-both hovee - Iring at woto-maenry, onfpentry, bohenioal arawing. coapoetng, prose rook, bindery, eating. millinery.

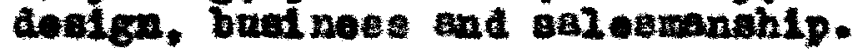


the shop roons were laft with conoreto exposed.

the ground noor of the ballat locker rooms and tollet room for both boye and girla and shop tor whet betal work, bullding trades. cablant work and mohine rork. The flret, or waln Hoor. conteinod the sabinietrotive sulte. Baloe room for dieplaying produete of the wahool, sewing and mllinery rooms, bindery. prese roon, Inotype room and composing room, an the wooond, or top Inoor, contelned the moohaniesl and arehitectarnl drawng room. eleotric shop and plnwbins wop. and four roome for the

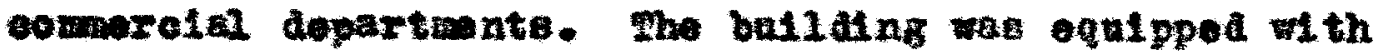
a frolght elevator for handilng all hoevg ateriala tread in the shops.

* oomplete flexible syetem of eleotrie wiring wa Installed throaghout all shop rooms fith brase ontlote in noore and colums, oo that achine weht be set at any polat in the bullatno and conneoted to the - Leotrio current lthout tearing ap any of the floors or wails. This provision was de so that chnnges in the ahope might be to kesp abrestet of the rapla ahenge in the indnstrial world.

All ahope were equipped with two roow with 
spedolly bull tool ckses, lockere, racke, bins, eto. ase and veter ocanestions were provided at comrentent plscer in all hop rooas.

The ballatng whe complotely oquipped wh new Imrniture and the latevt type of bodern mahlnery. All wohines in the bullaing were Individually motor arlvon, thereby exintnsting orerhoed shafting and bolting, and reducing all poesbluty of soeldent to prsetionl mintem.

It was in ench plent ta the thot soniovilo's now edreatlonal unlt whe to be houbed; from this neoount of Ite foolition and aquipment it may be sen that overy preparation had boen wade to houed it woll. The

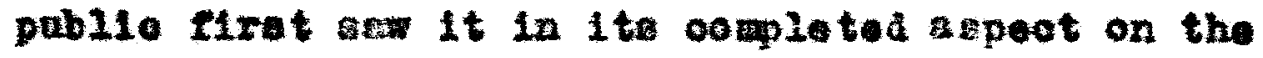

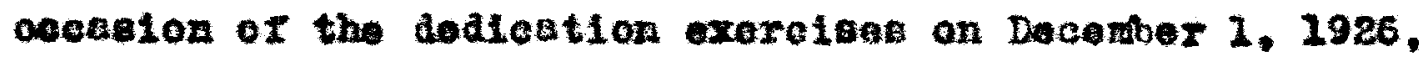
and It is an acount of thrt oooseton which now collows.

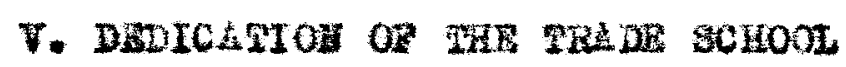

The tize for the deateation of the theodore ahrens srede Sohool wae chosen to colnolde pith the convention

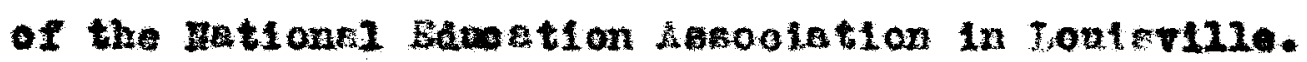
Wany 7181 tore from the oow ontion were prenent at the axerelese on December 1, 1926, and the now hullaing was wuch praised by many of the visting authorities in 
roeational training. 28 Dr. C. A. proeder, direotor

of the Damoody Inatitnte of Inmeapelis, was the groet

of the Lopierille Bonre of Education and the ohtex

epeaker at the cedicatory exeroloed.

fr. Leland payzor. Prealdent of the soard of

zenostion. preslaed orer the program. The acoptanoe

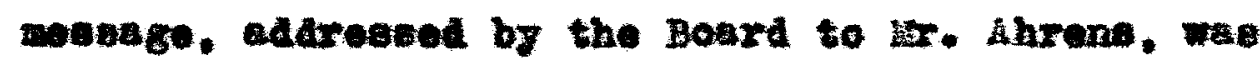

exprosed in the following words:

The Bonrd of Bluoetion, on It: om bohalf and on behilf of the altizene of hovietille, seoepts Wth prezound thanks and s deep wenbe of gratitnde. the eplendid gift of $\$ 500,000$ tor a trades sohool, made to this Bonrd by 14 . Theodore Ahrens, an out-

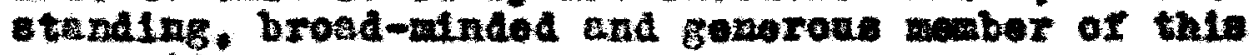
comentity.

The Board while minarul of the grest value and worth of the property thas generoesly bestomed, appreolatee no 2000 the liberal poblia oplrit whioh prospted the gxest gift and whioh mares ponelble the edveational developaent. along induetrial 2inos. of nuaberzese perteons tho tand in noed of the heipful tralaing whioh thie cohool will enpply.

The Board oannot too etrongly exprese 1 to binoere epprooletion of is. Lhrons" great goneresity and kindnesa and acenres hin that this achool. founded by him, will ever tand as lasting ponunent to his good nome and bleselns to the ladnetrial ilte of the alty. 29

The progran which wes presented on this oceasion

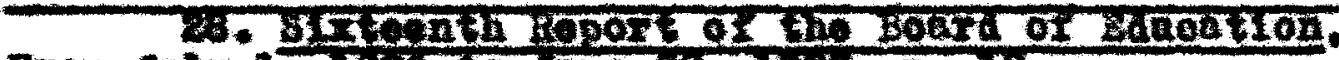

From sely 1, I9E6 to Jano 80, IVEV, D. IO.

29. Promen of the Dediction, Theodore shrens

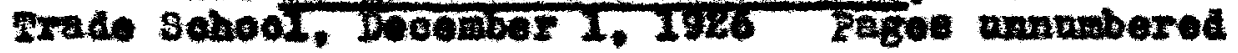


was as rolnowe:

$$
\begin{aligned}
& \text { Iavooation..... Dr. Jokeph Boeh } \\
& \text { Seleotion ..... Lonievill smle High sohool } \\
& \text { Oroheatra }
\end{aligned}
$$

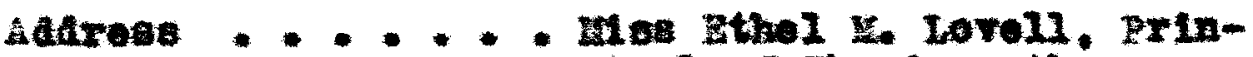

$$
\begin{aligned}
& \text { cipal of Theodore Ahrong } \\
& \text { rede Sebool } \\
& \text { Addrese ...... Hr. Thoodore Akrons } \\
& \text { Adarese . . . . Harry Fltzer. Papll of } \\
& \text { Theodoro Ahren Irade Sohool } \\
& \text { Addreas ...... Hr. Erron Eertieg. Saperin- } \\
& \text { tendent }
\end{aligned}
$$

Inepeetion of the 8ohool

one of the highlighte of the progrem, of conres,

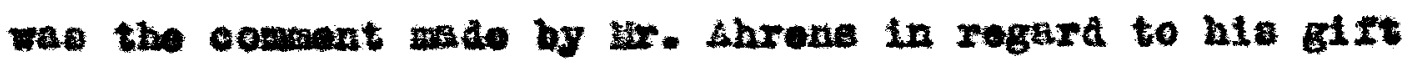

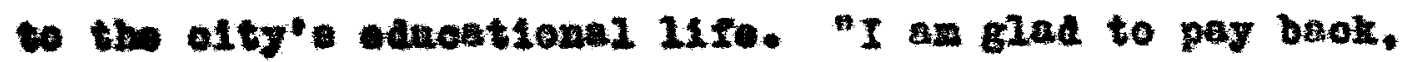

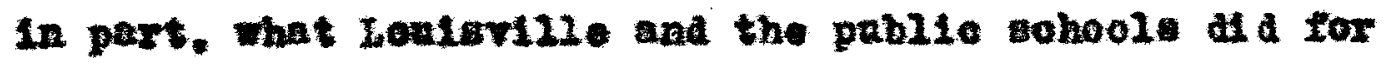
me 14ty yeare ago, when I was taring up ifo work." osid Mr. Ahrens.

"I was dented the opportunity of roostlonal tratning. and a.1 wy $11 \mathrm{fe}$ I have telt the laok of thorengt gretematio training in the trade which $I$ eelected for a life work," he oontimed. "I an glad, 
7

therefore. to bite the younger beneration of the of ty a better ahance than I hat in the ago gone by.

"Another reanor ror this gobool is the pot that the old apprentice ayoten 18 largely a thing of the

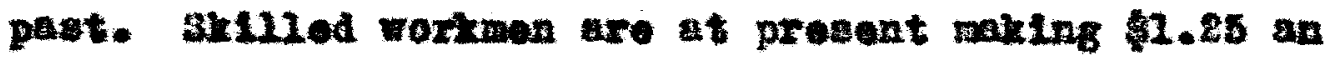
how and are too buag to gtre moh tine to teach yoans workan. ard bo this cohool is neaded for thalr treining.

I hope that the chool is only begiming and that 1 wil coon be noseasery to couble it, and in the noax Inture that the Eofrd of gineation w112 Ind 1 neoesary to bulla another sinilar sobool ceroted to

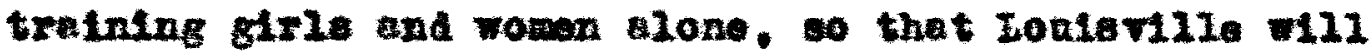
have two schools of this type. one for uen and boys and the other for vemen and firle. Let we ag aboln this 18 only beginning .80

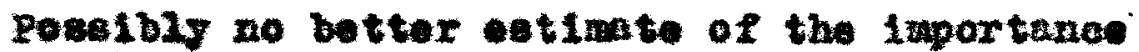
of this dedieation an be fond than in tho editorial aovent of the Loulerill, press on the rollowing any. one exraple of this oomant is quoted in fall;

Ith the dediention exerelses of weaneeday

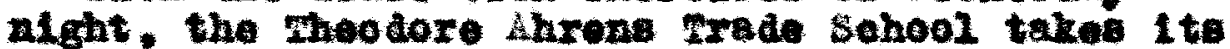

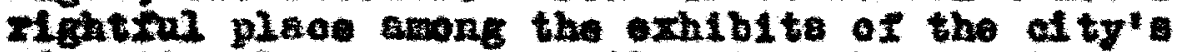

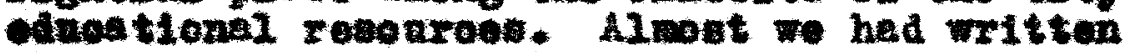
that 1 terea irst place. 
At the same tim It etende forth panopled and prepared among those ovlenoes of discerning and conetruetive genorenity of whieh, antil very lateiy. Londevillo had but fow.

50 Theodore Ahrens, modeat, retiring, welsexrecting to fant. the Herail-post tendere every expression of that high appreolation whioh met III those tho have for yeare had the best interest of the cahool te heart and have labored, wth roles and pen. Irrelesaly and contimuonaly to bring the plant contronied by the Board of panoe-

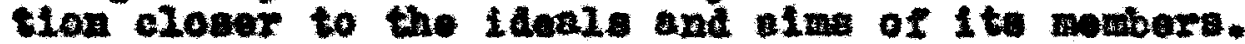
The Ahrens poundation $2111 \mathrm{~s}$ gap in the pobebe.

It does to under anep loos of most nnoomnon advantsge, sine the planning in all the olsboration of It many dotalls, hat been undertaken by the benefactor himelf, an thoroughiy well equipped with the regnist to knomledge and abreast of the 2atept developmente in that ine.

Wha it we found that the original gift wowld not enefice to earry ont the intentlone of 2 Lhroas in all their coaprehonalve amplitude, bo gave adaltionni fund at one and the compted

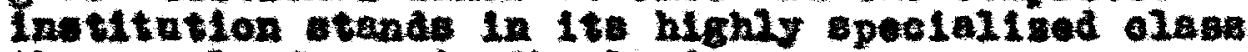
the equel of any in the Iand.

Just whet ouch achoole have wennt to other elt1es-the one of Clnotmati ocenra to ne right awby-comot caelly be grepped all et onoe.

Jnet whet the Ahrens 8ohool te gotng to so to Loniovilie 18 Impodetely orident in the mang applications for enrollanent. An the wonthe sad jeore pese by still the woader will grow the over the ctreetion of ow joanc wan and wowen can bave been thought couplete withont it.

Lark Dee. 1, 1926, with red lotter.

Let it atand henoetorth and for 811 tive to come rabriested in the oalendar of the Sohool Yoar.

And roguleriy and plonely. Iet it be oot esida a a cay for appropriet to exerolewe in which the ferethought no leae than the ilberality or Theodore 
Ahrons recolve thoir juet and propor dne.31

gratse of th. Ahrens and of the school he had rounded were forthcondig from every gaorter at the time of ite dediotion. then ealtorisl and oral preine had oxbarated Iteelf. the form of poetry wes roeorted to

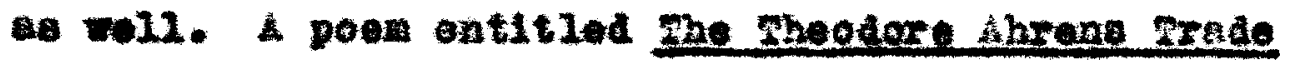
Soloel sppesred in the Herala-goet on Deceaber 4, 1926. Luthorahip was not eredited. One of 1 te several verees

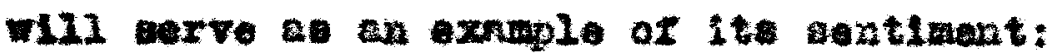

Ah. Gonerous ofty bulialer no rain thought Inaplred this glit and now way root and reter

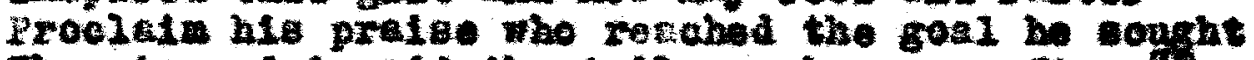
Fren turnod to ald tho tollore who oam axter.

The oonplete institution was now ready fer the funetion whieh It founder and his oa-morizert had onrislowa for 1 t.

preceding pegen have ahown Its atelopmont from -and beginuings to Its achievement of a large cepactity for the entollant and tralning of industrial atndents. It ropalne to be seen ony to whet degree the mheodore Ahrens Trade Sohool hes realised the prospects antiolpated ot the tisp or its dodication.

a. Whe Heralo-108, Dodober 2, IV26.

32. Ibla., Dacember 4. 2926. 
CHAP 2 IV

FURTHA DRVLLORHA: AHREHS SIHCE 1926

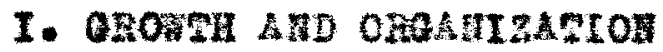

The Theodore Arrens frode sohool, the new "Berrice etation for the roostions," as it wa ealled.2 was opened to etulents at the beginning of the sohool jear in the rall of 1926 . To the lnetitution in that yetz and in those rollowing, vero to come hwarede of boge and girin, and mon a womon, all ceoklng prepsration for the problezs fast ahend of thom. Sone were in conroh of the right ine of work, some rented sill in handing the tools of edncetion, and sowe riahed to use this oduostion in moking 11 fo wore satistictory snd Loufsville a growing. progresalve elty."

The nusaber or paplle enrolled in the trade school continully inereased trow jest to jaar. During 1926-27. the firet year of 1ts operation, the enrollswent flguree were 617; the following jear the numbr wes 322 , and in 2920-29 1t reached 392.3 This growth kept np. unti2 in

1. Whe Hereld-rogt, Wotomer 25 , 1988.

2. Civic oplnion, oetober 17, 1926 .

3. The Iighteenth ileport of the board of gdugetion, Eron september 1. 1028 to antet 31. 1529, p. 16. 
1940-41, the 1ateet yoar for whloh figuret are avn11ablo, tho enrollment Fas 1287. 4

In this respect the night sohool olesses kept

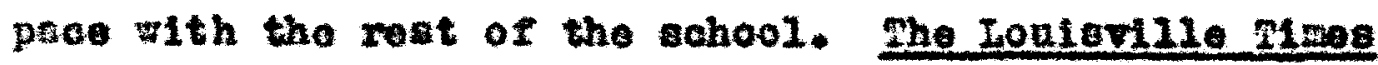
found the helghtenod interest in the night sohool worthy of corrent in october, 1927. In thet yotr. the cecond of the ochool's hatory, the largeet inorease anong all the night schoole of the efty wes that of shrons prede school. 750 onrolling as compred with 359 in 1986.5 That this trond has continked wey be eoen from the Irot that the totel night achool onrolimet for the year $2939-40$ was 2089.6

So phasos of roostional gtudy became dosiroble to add to tho conre of etudy. In viow of this expenaing onroliment, that is. Ahrona, arter the ochool wa opened, provided a gitt of 350,000 for work not at

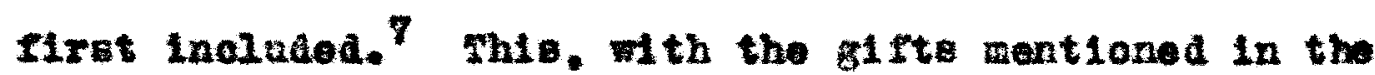
preouding chapter, brought hie total contributione up to this time, to $\$ 350,000$. Bven thla wos not to be the

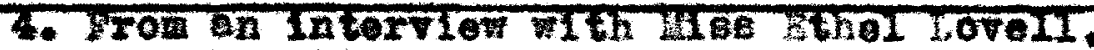
Brinotpei, Dotober 18, 1340. Ht end of term, June 1341, enrollent was 1478.

5. The Lonierille 2laes. October 5, 1927.

6. Interview with Ilas Lovall, Dotober 18, 1940.

7. The Herald-zort. November $25,1920$.
} 
Iinal evidence of hia interest, as in this chepter.

The Pnowity or the ingtitution. of course. grew as the ottadent body lnoreceed in numbers. For the eohool gear of 1926-27 it lnoluded twenty coven inetruoters. By 1940-41, however, there were fifty nine teachere, Inolualne zales lovell, employed at the Theodore ahrene rrade sohool. ${ }^{8}$

In apeaking of the orgeniagtion and plan of the Theodore Ihrons Irade sohool. It showl be emphesised that it is a freo pablie high oohool. To enroll, a pupil must bo t loagt fonrteen yoere of age and aast have satiafectorily completed the funtor high sohool. Hel of obch day is dovoted to a trade course. Which the pupll ay elect: the other hal is devoted to related sondenle work and general aomdento subject. The sohool is in seseion from 0:30 to $3: 000^{9}$

This enit in the adrational greter of louidvilie wos planned as senlor hlgh school. It offere tro. throe, and fonr yenr conres. and the provielona or tho Pelercl wath-inghes sot, which require throe

\footnotetext{
8. Intervie Fith Mgs Loven, october 18. 1340.

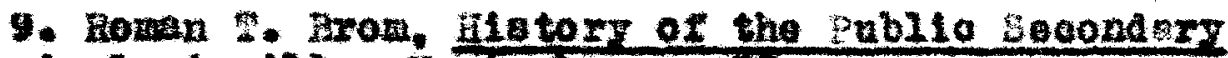

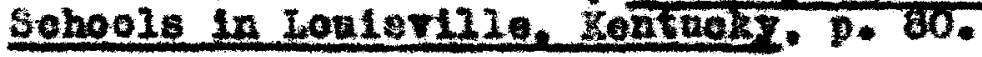


hours of ahop work and three hours of related sobdento etudies. In adition to day operation. are the night clsases. In the trades, unit oourees in bequence are nde pose1blo--for example, In the masony trade, anit oonxse are provlded in conerete work, briok laying. tile setting. plaztering. and peinting. 20

The departwont of night Eohool olases her been

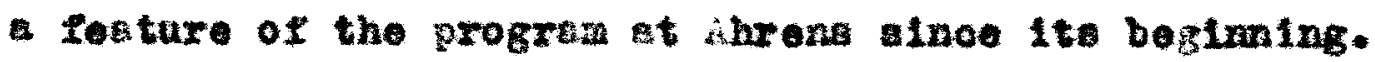
4t present it is hold for four houre eech week, for two hours oech kondey and Fuesday alght. The courteo given ere declded by regneste the by the paplle. The anount or work given in tho nlght achool is determinod by the anone of money allotted for this puxpose by the Bonra of Eduestlon. 21

The school keeps a reoord of all puplle. grnduatee and withdrews. On this permuent record or graduste otadents is reoorded the neuel better lound in sooh records, namo, elementary ochool ettendod, Juntor IIgh attendod, adsross, Intelilgence quotiant. test realte. Alte of birth, newe of parents. platniy opaced $1 \mathrm{~s}$ eleo the depertment in which popll 18 plseed. on reverse aide of thin crid ere recorded subjecte

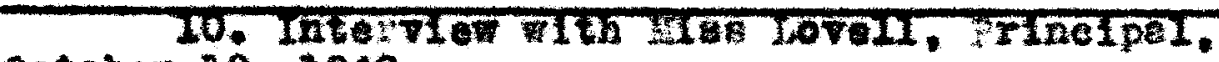
cotober 26, 1940.

\section{Ibla.}


cerried ond grodes earnod in winth gre or Jumlor High and epree for the entire academic record while In trode Bohool. I Iow blenias at bottom of this page are evellable for current aocial history. Upon gradustion an axiliary aheot is added to the record of each papil. Thie lo adjuated to hang orer the peraazont reeora card. on it is opece for recording the employrant hietorg of the pupil, and aloo there appears on thin auxiliary oheet record of personel qualifteations, such asitiative, echolerahip, health, ofrort, eto. There ere fourteen of these quslities listed. The ovalustion of these qualitles lo an eveluat1 on nrrived by compiling the opintone of all the teachere tho have taught the indivianal pupil. These oplnione ere reoorded on lnditidal alips and so are not bised opinions, no teacher seefng the oplnion of anothar tozcher.

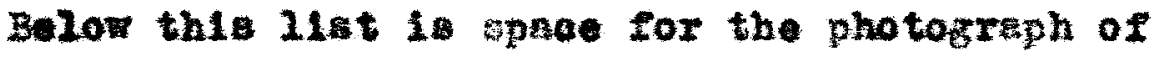

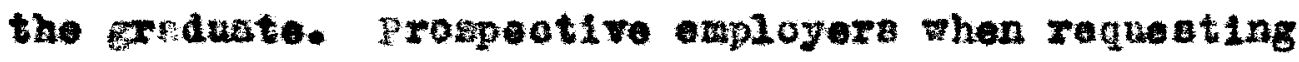
help ars inpresed by thl record which they consider more valuable then the graden on the erra. The indide of this auxiliery bhent is ruled and is need for confidentlal informetion rocetred abont the gradnate. I2 
The Paculty of Thedore Ahrens Irade shool

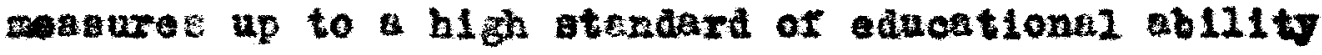
and training. Al1 techers of scadente subjecte neet the ase eductionn requirement as other teachers in oecondury achoolb. All tanchers of related (to trate) ceadomie aubjecte ast heve degrea. In addition to trade experionce in the lino related to their eubject. 13 Shop teachers ast have completed mll apprentlceGhip in trade. Al wo theg wast have had foarneymen

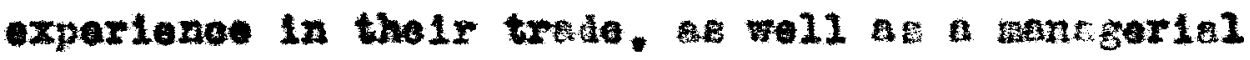
(appervinory) or for omaship apsolty.14

Studerta of this institution met do more than

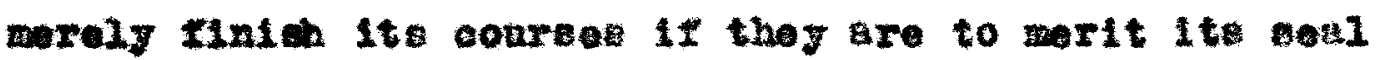
of aproval. utac Lovell has expleined that tho theodore Ahrens Frade school "places no atap on ita

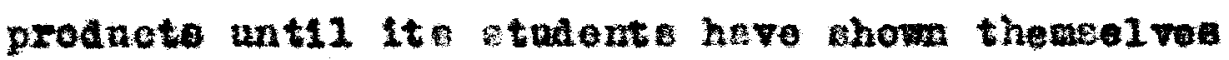
worthy of tore then were graduetion." Ae guarante of thoroughnes6, the otudent wat have o ninlan of three wonthe ancoeseful expertence in his thosen trade betore certiflcato la granted him. Some students have sttended the sohool on part-timo bablo. ining helf tial to school and hale to 15. 18IC., Oct6ber I8, 1960. 14. Ibla. 
2 job. Such obse hsve alwayo been piven spoctel attention and coopertion.

sany atudents through the echool are working on cooperative plan. When ventore are in the 18st tera of the conree, thay are placed in shope. In the rotall aeling copnrtmont nil studont are expected to work alniman of 500 houre durtag thelr tralaing prograp in eolilng. These sro not placed on cooperative gobs until they here hed fundemental work in the theory of retail enIIIng, and se they develop in anderstanding of principles of belling. and their personality and fudgent satures, they are placed on a part tise program of selling. These pert tine puplis are placed in our leading shope. Shis weane thet by their time of gradustion they hive earned permanent posttione. Whenever poseible, the school will plnce 8coond tern eniors in part tis shop jobe in ine wh their tratning. Bo that tho achool mo know the atudent" progreas and adjutmont to prectleal oftuetion before 20kving Behool.

Credit for work doro in 211 ohop depertwento is on \& Inboratory beste. In every trado shop tho stud ant worke three olock houre per dog. Fhts time is in fonr corty-five minute perlods snd ortitles the otufent to 
two high wohol oredite. Sach elngle period claes onrried flve daye por wees entitlan the otadont to one high school credit. All tudent upon gradustion mot hare earned 34 aredite or 17 Camegie unte. 16

The proportion of fallures in the consen the oohool 18 emall, acoording to Bfas Lovell. In effort lis rade to teach puplize some trede--if they are found not fltted for one, they are changed to sowe other conrse. 16

In examing the organigation of the school at the Iateat possible poriod of ita growth, the ecademio unb jeote required in 1940-41 ehorle be nased. English 10 a required abject esch semeter for overy pupil. soclal studies, too, is taiken by onoh student-atserioan History for the pupli of tenth grade 1evel, Boonomios for the papil of eleventh grade level, and "Demooracy In the saking" for the frolfth grade pap11. Also on the required 21st are selence, Inthomtles, Irawing. oto.. whenever thay aro relsted to any perticular trace belug stadled. 17

The etraes pleces on the physlasl treining

15. IEIC., Wovemer 20, 194 .

16. 101d., dotober 18, 1940.

17. roid. 
progran has been olsowhore oxaminod. It is noceseary to antion here only the particlpntion In Physteal sadoation et the trade achool is one handred pereent. whoh 18 to any that overy one of the regular gtudents 16 enrolled in one or more olabede. To perlode a weak are given to this aotivity. regerded as so vital to those expecting to $g 0$ out into the basinese world. "Iqual developrent of elnd and body" ws: the slogen adopted by the sahool after the IInsi completion and oquipwent of the spmastum. 28

The following is a copy of the conre of atudy at the sohool in 1935. It comprised two yeare of work:

Bookteeplag

Cabinot Haklng

Comberolal Art

Comerelal conrte

Dratting

Drasanang

Deotrictuy
Solenoe, the thentiea, Draving. Ingl 1 sh. Soolal solenoe

Selenoe. themet1er. Draslag. mglien, soolal seleneo

selenco, thematien, Englieh, Soclal selenee. Hetory of hrt

Stenography. Fyerriting, inglish, Boolkeeping, Conarolal iew, Soela1 Solence

Solenee, Hetherstics (Inoluding advanced ifatheratica). Bnilien. Soclal Delenoe

Fext110s, Sat thom tios, Design. Bnglith, Soctal Selenoe

Selence. Hatheres, Drawing. Buglish, social selenot 
Hohine shop Selence, Whomelce, Iraming. English, Sootal Solenoe

Printing

saloomenahlp

Sheot letel
Solence. Dthemetion, Design. Batish, Soclal Solenoe

Toxt1100, Wh thentioe, Design. Eation, Soolal Scloneo

Selance. Me therst lov. Drawling. Englin, Soolnl solence

Choras inglo and phyelonl Janoction are requiref of all stadente. Blectives: Wlec club. orcheotre. I9

Swo nea conraes were added in the behool year 1941-42: Automotive Shop. Inolual ag the stady of automob11. and alrpleno onglnes, and velding. Involving ges and electrie treining. Sho secooleted abjects belongIng to both these courses were sclence. Inthomatios. Shop Drawing, Engliah, Sockal Sclence.

In Chapter II wach was oald about the coursed offered at the old Vocntional Sohool. Whese oourges were retalnod in the ourrieulaw of the Lhrens Prade School Fithout any ohange exoept that made by the 1aprovoment in equipuant and general facllitie for gtudy. Snch

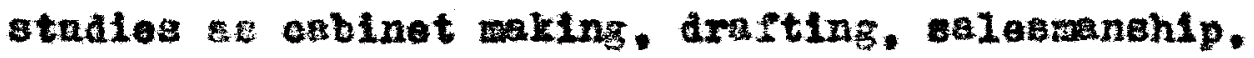
eleotric wring. book binding and dreasuding had been a part of the Vocational School's conres geare botore the Fheodore Ahrens rrode Sohool was posalble. 
Reforence has been do to these bofore and 111 not be noeded here. idditional conrses, however, were orfored when the new plant openel, wheh sheet netal work, pluabing. Hinotype operating, and mL11nery. St111 others were ade avallable 1eter from time to tiwe the opportunity orterad.

Bach courge wes provided with apercte room Iitted with the neerest possiblo reproductions of cotukl working oondltons. Studente in plumbing. For Instance, morked in a roop ifted np wh booths to regeable the difierent compertmente of a houee. Bvery effort wa to render the projeot more prsetieal than theoretioal. Bach newber of the raculty vas a odilled tradecan who had proved groceseful in his ovn Ine of work and who had taken courses in methode of tecohing. Hl the notidento pork regulred vas in airect reletionehip with the etudent'e trade. There are atany neeful exsiaples of the wey in which trade ond condexilo abjects are correlated at Mhreas. Bnstness 3nglish may be atndi od in coordination Ith courseg in Iitertiture. Girls enrolied in

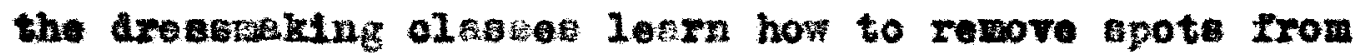
materiale by inveatigeting chemed ingrediente. afficlonoy and tio-beving devioes are two of the 
woet important problens to be colved by the theratios c1ses.

An Lovell hav sald in this connection: "Tlae eeving devioes for the elupleot jobs are abjecte for reeerreh ell over the country. Fegohologis to are taking an active part in ellaineting putstol coergy. pur young people are taught to take these probleme serlously. and their Imortance is obvlons in overy dey oocupations. I have observed untrained worker engered in eimpo occupation like stringing tage using three tives es moh mergy wa tive as necebary."

H121nery at Ahrens prade school to an interesting 112ustration of the type of conrae open not only to papils of the usuel sohool age, but to older Individusis who have not beon adoquetely eguippod to teise their places in the work-0-day wor2d, and whe jet desire to learn trade. While the stadent io lonming this trade, whe seer, handleo, and tortw with waterlalo which eatoh the oye wth their color end brilliance and eventusily develop into charsinf, protloal prodnete. Clages in baking. conducted th the eld of a large arry of beistag shop equipant. Fere an Innovation in 1929 which attrected considersbie attention. 20 the 20. the HeraTa-post, Haroh 15, 192\%. 
cleseen vere hold four daye weokly and pere eponeored by the Louterillo Jeseph Zistler. E baher, as inetruotor. The broad and cakes and other producte baked by the studente wero sold in the sehool ceteteria. Another renture, connected with the night Bchool. was anuenal enongh to evoke ooment. Shis war a clace for fourneymen plambers:

- . The journoyman plumber. be it known to the winforwed. Is to ail practioni intants o graduato in his sobool of tralaing. which lncludes four you of work as an approntice and the satiefootory peseing of an exaraination reguired by the city and given th the city Ball for securing his 11 cone to to pleoblng work. Thero is eo wach to be lefarnod, however. In the voection that large opportanity is afforded for luprovement in a grtidus te ochool, and so a nlght alese. or rather three night aleaces of Bbout twenty wen esch, gethor on oertaln oveningo of the week for work at the Ahrene mrade sohooj.

J. 0 . 1121ans 18 instructor. Iathematica. solence and shop arreing sre the ubb jecte covered in the course. Fith prect10a1 Fork in som of the wot intrieste problew of plubbing sotiritios. Dravluge ere asde frow all angles of the work. Complote lapoute in plumbing IIxturee gre sketohed by the night echool etadents and some of these are a Inlahed in appoarange an architect's arasing or a chart in phyelos.

Such activitlee ae theme geve oridence that tho aduationel progren of the three " 2 'B" had been brondened

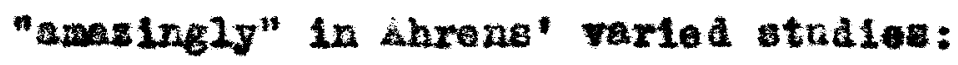


Today the adult a well as the jouth Beoke a claseroos to gecure knowleage or training and the soope of edwotion has brosdened oo anzingly that practically every occupetion knom to man can be ieernad in the olaeseroom. Fether is it any longer novelty to find rather and son, or wothor and daughter. enrolied in the ame institution of loarning. 22

\section{IATER PHYSICAL EXPARSIOA}

Lo the Fhoodore Ahrens Frade School developed and expanded in 1 to educational services to the eity of Loulorille. Ite noeds inereabingly grew an well. Lgain, It proved to be the seeningly never-ending generoelty of 2x. Ahrent which matehed the ocossion with funde to seet the neod. In Hay of 1980, hardy fire jeare efter the Institution bad firet opened 1to doore, there was announced an sdditional glft of 300,000 . brtnelnt his donations to 8 totel of $\$ 650,000$, and bringing the velue of the technioal gehool to an investment of al Ightly ander $\$ 1,000,000,23$

The Board of Iduestion, In nceepting the gift. agreed to provide the property on which to conatruct the addition, and sthorized semel D. Jones, businese arreotor of the board, to purehase sdjolning property

2x. IbIs.

23. The Courler-Journal, thay 17, 1930. 
to the north of the ohool site, at 546 sonth Miret Street, and procoed wib tentetive plans and spealfiontione for the new bullatng.

Hr. Joneg lndioted that aotual conetruetion of the building aght be started within $31 x$ or elght months, ond that it alght be completed fithin a year. Options on property north of the school. Facing 276: leot on Firet stroet and ruming bnok 200 foot, were being worked ont by $\mathrm{k}$. Jonee. The board authorized payment of not nore than $\$ 100,000$ for the property. and ho ald that condeanetion onita would be illod if prices were found to be beyond the price 11 int. 24 Aotwal1y. howeror, It we bubequently decided to inveet thie glft, and work on the now sdation aid not etart ont1l after is. Ahrone" desth in 1938 , oven though plans for it were epproved in late june, 1936, by the C1ty plenning and zoning comalssion. $2 b_{4}$ pablio Worke bdminiatretion grant was belng soaght to asblat Wth the work and this Gram did not aterialize until the later date. Aoknowlodgement wa be be the Bord of zacation the latter paxt of Jane, 1938, of a pablio Tork Adniniatration grant of \$259,503 for the

$$
\begin{aligned}
& \text { 2. 1are. } \\
& \text { 26. Ib1d., Ja1y 1, } 1936 .
\end{aligned}
$$


oonatruotion of three-atory briek and conorete addition, 26 and the Becretary of the Board of Eduction whe requested to send forwa notice of the grant to Lro. Zarl Lang. the late ur. Ahrena' daughter.

The oonetruetion was to create now wag of the trade school, thros noore high and $170 \mathrm{by} 200$ feet. The cost, reported the conrior-jourmal, 27 was 3354,000 , and was to keep 260 men working for fourteen monthe.

The new ballding was a north wing of the group comprising the school. The flret hoor contelned an auto achanio' ahop, a sele a gulte where producte de In the school would be cold. three clase roome and lockere, storge and other rooms.

The second noor contained an electriesl ahop. three olags roons and a librery, as well as torage, looker and other rooms. The third noor contelned a arawing rook, two wemlag rooms, rolated arte room, a

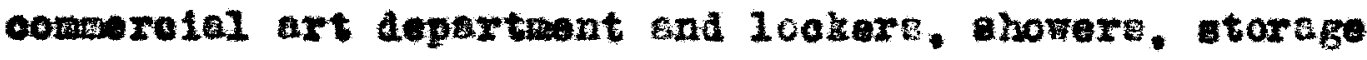
and other smallex roows. 28

Wr. Ahrons helped in prepsaring the plank, the

86. 1010.. Jary I, I938.

27. Ibia.

28. Ioza. 
bosrd explained, and had given approval to the layont betore ho died. The plane were prepered by Alfred Feineded. arehitect, and the onglneering fostures by verron end homald, engineers. 89

tork started on excaration for the ndation in Hay. 1938, arter Lrs. KorI Lang. danghter of the late Theodore fihrent, turned the IIret shovel of airt in exarcised ettended by Bosrd of Education and pablic worke dalnibtration officlals end civio lenders. Precentation was ande by Bailaing Inspector Erhert of the 239,000 contrect for the ballaing to George $\mathrm{A}$. skelton. Sr.. of the skelton construction company. 30 So began the last fact in the tory of moodore Ahrene" generosity to Louleville eduoetion--began fith the chlel actor having glrosdy completed his role in 21re. 31 Behind his rema ine the theodore Ahrens Srade Sohool a his worlal. A lasting memorlal oftizens of Loularille sgreo, In a sentisent expresed by an

\footnotetext{
29. IDr.

30. The Loulgyille Mines. Tay 15, 1936

31. "In 1933 st Theodore Ahrons" Trully preeented to the echool a portralt in oll of is. Ahrens. Bven ithout this constent reminder, tho boye and girlo who have attended Theodore hhrens irede sohool will never forget this publio opiritod gentlomsn. who made so woh poealble for the in onoh a practleal way." -

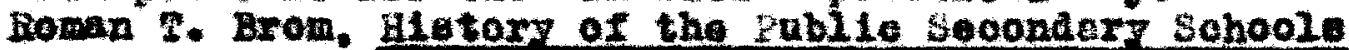
in houlev112e, zontrosy. P. 81 .
} 
editorial of a deosde a.go:

- Vooctlonal sohoola, trate ochoole. instruotion by experte in the handicrerte. know2odgo of ehoulatry prootloaliy opplied, bullains ae well a erohiteature, how to lay brich. plubbing. the hargeasing of eleotrio poner. printing. and so forth, all these and many wore have . - becom Importent sphered of edueation wherever the opportant ty has exleted.

For the wet part, and in Jobieville nore partioularly. onch prorifion hes hed to come tron private generosity rether than from the publio tandin.

Firat, and all but sione, in that noble dedieation to the peeds, that giendid reapones to the oall of hio follow eltisens, both of today and of tomorrow, stande sheodore hirens.

It tes be who, in the firet inatanos, propided the funde which ade poselble the orection of the rine plant alrosdy in exiotenoe. As 1te atility hae wore and more been denonstrated, an its place In the echose of ednostion has grined in importance. co IIrewise hoo the neoesalty of expanaton.

Accepting that derelopment be duty. as a responsiblilty, Aprene now comes forward in the woat moget way in the worla to duplloate his Benerosity. $8 E$

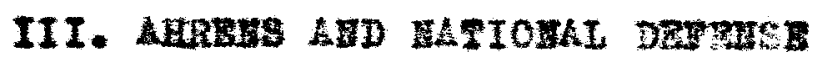

In the oarly swaser of 1940 when the mechanised etrength of verwen's aliltary rorces ahe tered the atenger of Brance, the dawocratic netlone of the rorld beome donbly alnrmod for thoir security agalnat aggreation. The Buropean contliet had proved alresd 
that indugtrial ernclonoy in the wanurature of plenos, tenke, and other escential equiprent in modom writre wag a factor in derenoe prepartione et leset equal to the mobllizetion of a nation's manpower. Ao a resalt of this development. the onlted states, aroused to deop conoern over its position in worla afrelre. began to prine ito induatrial tochine for suprene effort to manafocture the neterlals of war. The gigantic alus of this effort to produce Eohines and terisls soon we oloar the shortege of trained workers for the saded demande of the defonse program. Avery avellable man wat pat to work, and the call wa for gtill wore 00 goon as harried trelning could prepare then for alace in the industrial plants. The vocationel echoole ooon found themelves nnder the heary reapondiblitty of proviang large mavare of this preparetion. Ahrens zrade Sehool was no exception. On the contrary. Wth the Dupont powder Plant and the gun plant newly loosted near and at Loulavilie, respeotively. It found ite progran grastly enlarged. In sdation, the expansion of air training reallitles st Bomban pleld made ite own partioular demenes upon the trade school. Thewe developsente ware ple plain in an address 
to the strent body of Ahrens frede sohool on noventer 1 . 1940 by $u$. Barry Hinghan, preetdent and publiker of The Fimeg and the courier-Journal. calling attention to the shortage of ek11led workern, Ir. Blnghaw etreseed the 1 upoxtance of reostional treining in his mage to the etuante.

Adaresing approximtely 1.000 boys and girlo of the 10th, 11th, and 12th grader in the ochool granasing In a aries of altizenmbip talks betore ofty high sohoole, 赼. Blaghan cala:

Fraluing to you as a bastnog 1 can't honestly say whe wondertal buel ness opportanlties are golng to be walting ror you when you get out of eohool. I oan say. though, that there has nover bean a tie whon rooational trainling has been a important as now.

- ilready there 10 ahortage of mon akilled in com partioular ifis and indnetry is bearching for tralned earpeatere. eleotrielane. plembers. mohentes and radio toohnielans.

Thoee are daye when overy wan osn do wore then wate a living for hizeelf. Ho oan help bulla ap his conntry by tralning hivelf for job and colng it to the beet of hie sbility.

The ekt11ed workman who can take a place in some vitel defonee industry is fuet as important to the Jetion as the beat oftioex in the frwy.

"uy gress it that we may be able to keop out of wer if wo ke oureelves trong and pnited and w. Will probably be puebed into war if we atay woex and alsunited." 38 
At the time of this epeech Ahrens Trade School bad alreagy hit its enl etrido in cooperation with the treining progran of the Rederal Government Anring 2940 and 1941. The tratning was of two typas: (1) Sppplomontary-giving additional exilis to mon alrendy ooenplea in wechanicel trede, and (2) Refreoher-for works Progreas Administration workers and anomployed who had had oode prevlous oontact with the trade in whoh thoy wated training. 34

C1vil Aeronsatios, Hnanoed by the Loulevilie

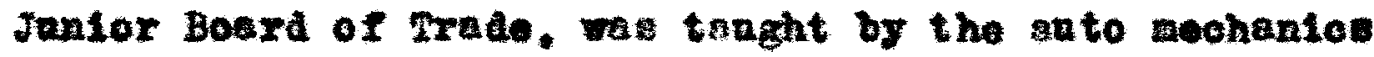
teacher of Ahrens as at111 another foetare of the cohool's perticipation in the national defende program. pollowing ten weoks of ground school. students waks the higheet grades on Rnel examinations were amried Alght acholarahipe. The couree was schoduled to open Deouber 1, 1940. In the Hovember precoiling, thirty Itre students had already onrolled ond o oll had boen made for adallowal ragistrants:

An additional reglatration period for men dodiring

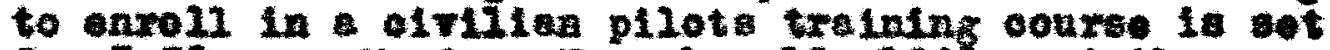
for 7:80 p.m. Honday Hovember 16,1948 at the

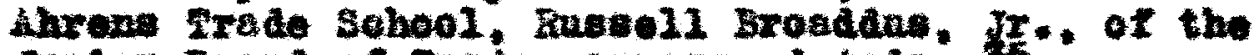
Jwelor Boerd of Trede, amomeed today,

\footnotetext{
catober 18, Into.

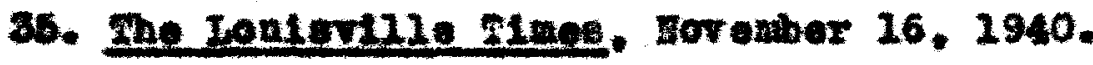


An additional note ooneorning thlo course

appoared in the Ilses for Daceber 14. 1940:

1 ith about forty atudent enrolled, the Jenior Board of Trade toang celled for IIfty wore to studs in arietion ground school clabses it is sponsoring ot ihrens rrade school.

The elseses, otarted this vect for pereons Whout oolleg tralning, are held from to $6 \mathrm{p}$. and 7 to 9 p.

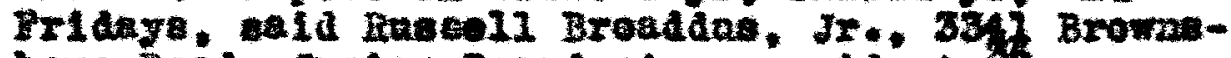
boro hoad, Junior Board viee prealdent.

Beating on the abo noor of the school early

In Decewer. student: found tro well-morn Aray tralning planed, "wehed out" of allitary aerriee, but restored to nw" neefrinesa in training young student weohant os for pleees on eirplane plent asably 11nea.

shorn of their wnge, tacheretera and altimeterw. the plones were expeoted to be of "treandous holp" to the oubol in 1te atomotive and ariation motor and sheot wal training coureer, eala woe Ethel Iorell. prineipri: 37

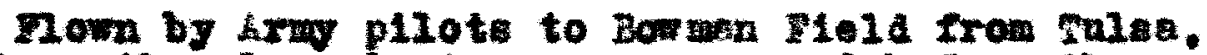
Okls., the planes Jinge were removed before they wero trueled to the trede ochool at $546 \mathrm{~S}$. Firet. The winge were taken to the school, too, so they oan be studied along with the treelage by tadents In the theet tel ohop for an insight lato conetruetion dotnils.

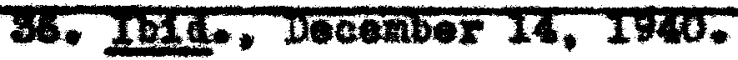

37. Gwoted in the Lonlor111e ILes. Deceaber 7. 
The notore are studed by sones otndent mechenies in eatowotive clsoses.

The array retalned the eltimetera gnd troheretere which show tho notor' rovolatlone per alnete. because there is ohortege of these Instruente

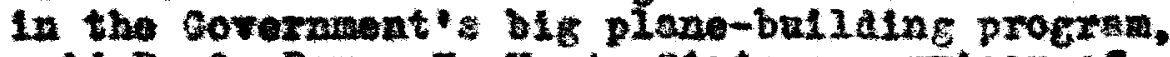

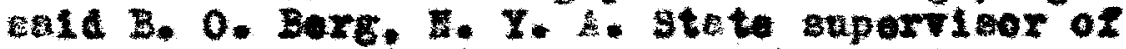
property. The instrawents oan be nood anceosstully in net plaves, he blad, ond wowd be of little ralue to ehop etrionte.

The planes were loand to the trede school by the I. Y. A., whioh has been given titlo to thom.

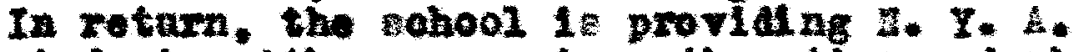
ctudonte with oourees in thosstic and bop oketehtng and orervoody conoerned is benefit ing frow the "evap."

Their once bright oolorg now a caded blue and ye110 , the 10 gear-01d, two-get mipe st111 beer on their elas phitepainted inceriptions. "V. S. Aruy, Fulea, OxIn.

The t10-up botween the fationad Fouth kdenietration and Ahrons montloned above resplted in the tralning of 200 yowng in jobe ossentidil to natlonel detense. In thalf work experlence shop ot 117 chspel street onehals of this gronp welded, hamered, oned, cat, Aled and ground at one tire-the other half, wornhile. attending quleter clabse th Ahrens Frade Sohool where the theory brak of the seohinee and thelr operation wo taught.

This wae the Irist Fational Youth Adalnietration wit of lie find in the stute, nocording to Bobert $I$. 


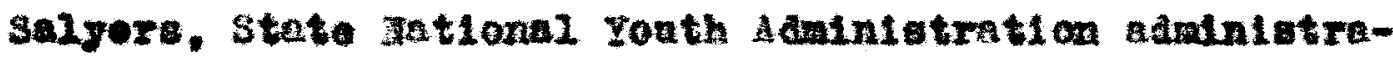
tor. 39 The pien wes in leeplng with the netionide trend of training son for sobs in national aefonos 11elas. Furtheraore. the prectice of cobining work experlence vith instruction relsting to the trpe of job was the approred methos of apprentioenlp. Boge completing tho course found work walting for than in almost overy inetenoe. B. F. Forry. alrector of employwat for the state istional Youth hadiniotration stated that the tarnover in the work experlence shop was ao high as 25 per cont a month. 10

In one ond of the large barn-11ke etrueture used for the worl experience shop is the sutonotive departwont. Hearby is the ohoet metal departant where garbage cans, guttering, lookerb and metal tables are made. At the oppealte ond of the roow is the pelating copnztient and the sohlne shop. Dosens of expensive wohines and rabobllitated mohinos are provided for the boys. who are cloeely supervibed while they learn to operate the lathes. the tool and ontter grinder, the eylindrles $g$ grinder. the fling. aswing and pollshing

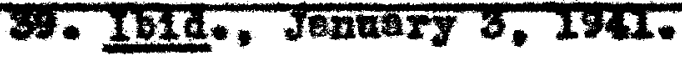

10. Ibed. 


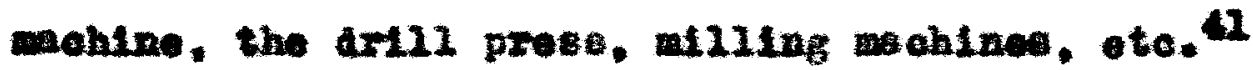
Dot only the young have sought Ahrens frade Sohool in preparlag tor the opportunities to work Which the defenes drive hae brought. Wliy clowes

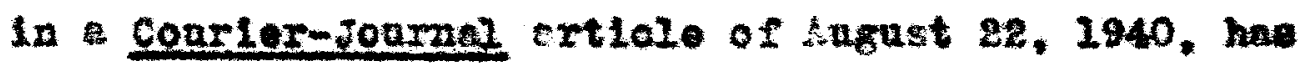
cederlbed the wnemployed, wlallo-bged men, who have been going beck there to sohool, to brash up on the trades at which they oarned a Liring before the depreselon. At that time there wore 214 of thom.

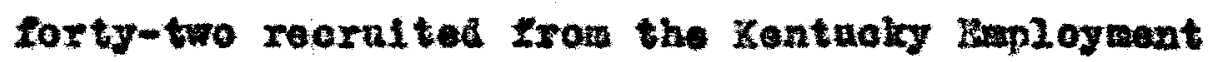
Serviee regiatration flles and oeventy-two from gorke Prograse Adulnistration ranks. WII had had some experienoe in trades mioh are usetal in defenee induetry--

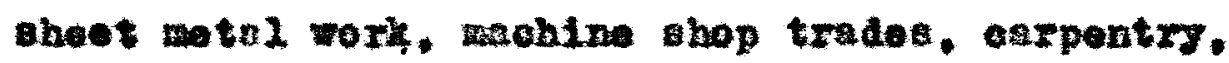
drafting. All of then were out of jobs when the new progres began. Loat had spent the laat ten yeara arifting from one texporary job to another. They now, secording to and fire days week, striving to ecteh op with trades that left then behina. They are Hilled with hope for betser timer, oten if wer mut bring thew 48

\footnotetext{
4. 10IC.

42. Helly clowes, Artiole in The courier-Journal. Augast 22, 1940.
} 
The Worke Erogreas Adaintetration group is pald atandard wages whlle learning. the other men mast anpport themelveo during the tralning period. the gronp is a carefully aeleoted Iiret araft of the mon now urgently needed in hoary induetry, but it represente only one part of the program. to ppedal night alagnes three tine weokly oom other mon. alrevdy at work, who are anxious for advanced training in thatr tratea. 48

The response, accoralng to Ahrens' prinotpal.

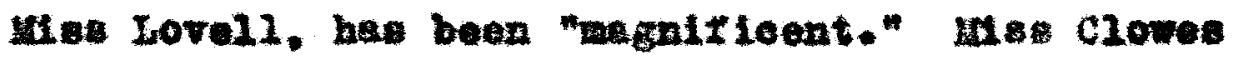
quotel her marther as follows:

There sre 1.500 wen who wowl gle dy take this prograte. They are Ilsted at the ployment Bervioe office and are only too anxions to bruph up on their okills. Onfortunately. they are not neoded In defenes Industrios and ao wo osnnot inolnde then in thl progran whioh the Federal corernmont 10 ILnanolag aolely in the Interent of derenes proparatione. 44

The progran w121 oontinue indafintsely, so long us money Irok mauhington ooded to asintain It. Certain ohanges in schodale wovid be necestery daring the regular school torm, atatad as Lovell, but srrangonents would be ade to have at least half the number of houre

3. 161.

4. Ibig. 


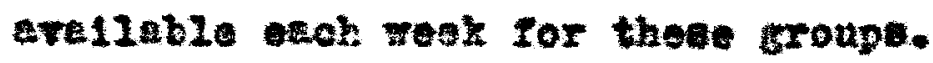

"It begln to 100k as though we'll ran Behool on twonty-fokr-hony bess," she eald, "bat the wole thing 18 eo enoouraging and the ben are bostened by the ohano of wort that none of would wind that a bit. Fe'a be hrppy if wo had a bohool twies as Iarge be this one to pat then $1 n$, and enough noney to take ererg applicant. $n 45$

\section{IV. corcutre I of}

Ilaportant the ourrent lesue of national defenes 18. 1t wat. finally, not be forgotten thet Abreas is a cobool primarily for paplle of the high chool level weeking meane to prepare thomedred for e future 11 velihood. It is a tree publio high sohool In mich every pupll met devote half of each sohool day to arade oourne wioh be eloot; one-fourth of the rewinder ie deveted to related bubjects, Inoluding thop solenoe, whomatioe and Draning, and onofoarth to Bnglish and soolel studies. It is a sobool In which high eohool diplom is awarded upon encoesetal oompletion of three yeare work.

Ahrens Frade school is achool in which the 
conree of etudy 1 a deolded by exploywant deusad, and It is changed and aeveloped in accord with Indaetrial snd trade advanodent. The couree of atudy listed provionexy of of the yoar $1935^{46}$ has thes, in the school geer of 1240-41. Foned it neeful to adi the departant of sutomotive shop 3tady and to adranoe plubbing to the statue of a fall depertisent of stact. Ahrens 10 cobool founded and dalntalned, ea hav been Indicated. by people of generone wotives of sartice, sa. Alarens in hie philenthropy and ues Jovell in her expervialon bave loft the Ir mark apos the inotitution. It is oobool in whoh gradnation does not mark the end of a comnection: it is lmpasible for ereh to be the ante where the polloy of tho sahool ia to keop in toveh $\mathrm{w}$ th 1 ts atudents inrongh questionnalro thioh soek infornstion whoh will ald in keeplas the stadont enitably and happliy omployed.

Ahrene 18 ahoel which was sounded with the purpose of flting atudent for thel ohosen oocuption in 11fe. Purposen of this thesis have been to shor how, in the first place, it It the plan of the nattanal norowant in rocotional ducation, and also. Indirectiy. It has becon an integral pert of the 
Indartrial 11fe of Ioniar1110. 20 sccomplioh theae parposes 1ta history has beon related, frow 1 to begleninga as tho tiny provooatlonal Sohool of $192 \mathrm{~s}$ to the preant yoar of 1941. 


\title{
BIBZTOORE PIY
}

\author{
A. Boors
}

Ieavitt, Prank M toho2I, and Bdith Brown, Erevooationel Edpostion in the pubzlo Schoole. Boston: Hogerton iristin conpany. 1916. $246 \mathrm{pp}$.

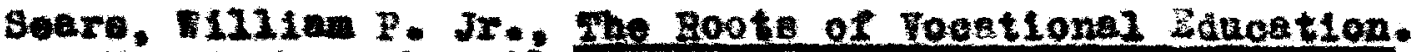
Hor York: John wiey and sons, I9s1. 3to pp.

Struok, 7. Theodore, Moundat loas of Indastrial sanention. Fen York: John Firey and Sons, 1930. G9E pp.

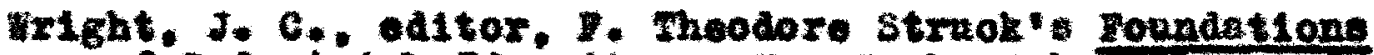
of Induatrial Zanostion. Fow York: John Whos and

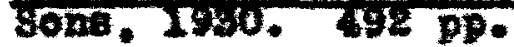

\section{B. PBRIODTChL ARTCLBS}

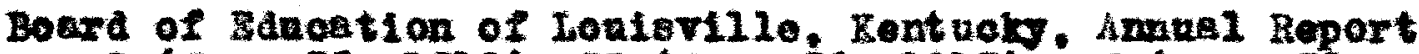
I (June 30, 2912): II (Jane 30, 1928): IT (Jane 30. 1925): V (Jane 30, 1926); VI (June 30, 1917): VII (Jne 30,2918 ): $x$ (June 30,1921 ): XI (June 30. 1928): XII (June 30, 1923): XIII (June 30, 1924): XVI (Jane 30, 1927): XVIII (Anguet 31, 1929).

Petere. H. E.. The Blemial Beport of the Saperintendent

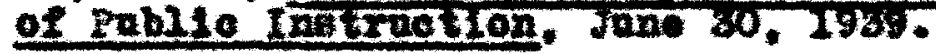

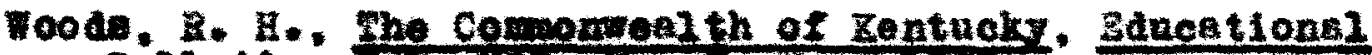

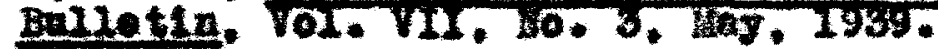

$$
\text { C. DEPURLISED MTRRIAL }
$$

Brom, floman F." "The lletory of the public secondsry Sohools in Louler1210 " Lentuoky " Mapablishod Haster's theals. The University of Rentroky. Lexington, 2935. 92 pp. 
D. ISTSPAZERS

C1rio Opluion, Dotober 17, 2926; Deoenber 27, 1924; Jane IE. 1986 .

Tho court ex-journal

The Loulevilie fermia-poet

The LonLevilie Eernile

The Loniovil1e poet

The Lonievilio rieas

clowes, solly, Artiole in the Loulerille Conrler-Jonrnel. Angust 2e, 2940.

3. OTHER SOURCES

Interview wth Hes Ethel Lovel1, 2rincipal, October 18. 1940.

Interviow wh thes athel Lovel1, Apr11 24, 1942.

Interview wh Hae Lovell, Hovember 26.1941.

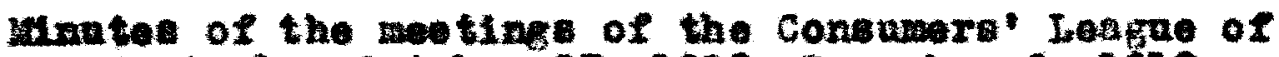
Eentuoky, Detober 27, 1910: December 6, 1910;

Rebruary 7. 1921; waroh 27. 1921; 棌reh 20. 2913;

Apr12 26. 2913; cotober 10, 1913.

Pereonal Correepondenoe of the inthor, letter from Hrs. Tari H. Ieng. Nov etber 10, 1940.

progran of the Dediention of theodore Ahrene Trade school. Deourber 1. 1926.

The outilne of Fork of the Conevere Leage of zentueky (a mavo graphod thoet, werch 13,1324 ). 